OPEN ACCESS

Edited by:

Johan Schijf,

University of Maryland Center for Environmental Science (UMCES),

United States

Reviewed by:

Torben Stichel,

Alfred Wegener Institute, Helmholtz Centre for Polar and Marine Research (AWI), Germany Brian A. Haley,

Oregon State University, United States

${ }^{*}$ Correspondence: Germain Bayon gbayon@ifremer.fr

${ }^{\dagger}$ Deceased

Specialty section:

This article was submitted to Marine Biogeochemistry, a section of the journal Frontiers in Marine Science

Received: 25 October 2019 Accepted: 03 February 2020

Published: 20 February 2020

Citation:

Bayon G, Douglas GB,

Denton GJ, Monin L and De Deckker P (2020) Preferential Riverine Export of Fine Volcanogenic Particles to the Southeast Australian

Margin. Front. Mar. Sci. 7:89.

doi: 10.3389/fmars.2020.00089

\section{Preferential Riverine Export of Fine Volcanogenic Particles to the Southeast Australian Margin}

\author{
Germain Bayon ${ }^{1,2 *}$, Grant B. Douglas ${ }^{3}$, Geoff J. Denton ${ }^{3 \dagger}$, Laurence Monin ${ }^{2}$ and \\ Patrick De Deckker ${ }^{4}$
}

\begin{abstract}
${ }^{1}$ IFREMER, Marine Geosciences Unit, Plouzané, France, ${ }^{2}$ Department of Earth Sciences, Royal Museum for Central Africa, Tervuren, Belgium, ${ }^{3}$ CSIRO Land and Water, Wembley, WA, Australia, ${ }^{4}$ Research School of Earth Sciences, The Australian National University, Canberra, ACT, Australia
\end{abstract}

We report on rare earth element and neodymium isotopic compositions in a series of grain-size fractions separated from river suspended matter in the Murray-Darling Basin (MDB) and a nearby marine sediment core (MD03-2607) offshore south-eastern Australia. This source-to-sink approach was used to further investigate the extent to which sediment sorting may control the geochemistry of suspended loads in rivers, and to provide constraints on the source of the detrital sediment material exported to the ocean. Our results provide further compelling evidence that significant sizedependent geochemical decoupling can occur in river systems, accounting here for $\mathrm{Nd}$ isotopic $\left(\varepsilon_{\mathrm{Nd}}\right)$ differences of up to eight epsilon-units between silt $(>25 \mu \mathrm{m})$ and colloidal (0.2-0.006 $\mu \mathrm{m} ; 0.006-0.003 \mu \mathrm{m})$ fractions. All suspended particulate samples from the River Murray watershed display a trend toward more radiogenic (higher $\varepsilon_{\mathrm{Nd}}$ ) $\mathrm{Nd}$ signatures with decreasing grain-size, in addition to differing REE signatures, which collectively point toward a preferential volcanogenic origin for the fine-grained inorganic particles transported by MDB rivers. Furthermore, we show that the same river-borne volcanogenic material dominates in the fine-grained detrital fractions extracted from core MD03-2607 at the south-eastern Australian margin; a finding corroborated by REE signatures in a series of copepod fecal pellet separates from the same core. Collectively, our results suggest that river sediment discharge is accompanied by preferential export of fine-grained volcanogenic particles to the ocean. This potential source of bioavailable trace metals and nutrients in ocean surface waters could impact marine productivity.

Keywords: rare earth elements, neodymium isotopes, suspended particulates, colloids, Murray-Darling Basin, Australia

\section{INTRODUCTION}

On continents, hydrological and transport processes can result in significant grain size sorting in river systems, which controls both the geochemical and mineralogical composition of suspended particulates and bedloads (e.g., Garzanti et al., 2009, 2011; Bouchez et al., 2011). Over the past decades, much of the research conducted on river sediment geochemistry has focused on particulate matter ranging from coarse sands to clays; i.e., the granulometric fractions that dominate sediment budget in rivers (e.g., Gibbs, 1967; Garzanti et al., 2009; Viers et al., 2009; Bouchez et al., 2011). 
The detrital fraction of suspended particulates and other riverborne sediments carries unique geochemical information that can be used to determine their geographical provenance and the degree of soil weathering in corresponding drainage basins (e.g., Gaillardet et al., 1999; Bayon et al., 2015). In comparison, the origin of the finest inorganic colloidal fraction transported by rivers remains far less constrained and understood. This question is of particular importance because colloidal nanoparticles have a substantial surface area, and typically serve as sinks and/or sources for trace metals, nutrients and pollutants in the natural environment (e.g., Hill and Aplin, 2001; Pokrovsky and Schott, 2002; Kulaksiz and Bau, 2013; Trostle et al., 2016; Gottselig et al., 2017).

Rare earth elements (REE) and neodymium (Nd) isotopes in river sediment and suspended material are generally assumed to faithfully reflect the composition of their source rocks (e.g., Goldstein and Jacobsen, 1988a; McLennan, 1989; Bayon et al., 2015). Correspondingly, this assumption has led to the widespread application of the REE and $\mathrm{Nd}$ isotopes as provenance proxies in various environmental studies (e.g., Goldstein and Hemming, 2003), but also as emerging tracers for anthropogenic pollution sources (e.g., Kulaksiz and Bau, 2013; Brito et al., 2018; Trifuoggi et al., 2018; Xu et al., 2018). However, it is now increasingly recognized that both weathering and transport processes can also lead to significant decoupling of $\mathrm{Nd}$ isotopes in rivers between different grainsize fractions (McLennan et al., 1989; Andersson et al., 2001; Garçon and Chauvel, 2014; Bayon et al., 2015; Merschel et al., 2017; Jonell et al., 2018). This has been recently illustrated in a study conducted on sediments from the Ganges River basin, which showed that suspended particulates and underlying bedload sediments could display strikingly different $\mathrm{Nd}$ isotopic signatures (Garçon and Chauvel, 2014). Similarly, several case studies of river-borne sediments were reported in which pairedclay- and silt-size fractions exhibited systematic $\mathrm{Nd}$ isotopic differences (Andersson et al., 2001; Bayon et al., 2015). To some extent, the above-mentioned differences between fineand coarse-grained fractions have been attributed to preferential breakdown of young volcanic material and its transport into the finest suspended load in watersheds. Alternatively, other studies have suggested that significant $\mathrm{Nd}$ isotopic decoupling could instead reflect processes occurring at the mineral scale during incongruent silicate weathering (Aubert et al., 2001; Viers and Wasseburg, 2004; Dausmann et al., 2019).

In this study, our aim is to test the hypothesis that preferential breakdown of volcanic material on continents could influence the geochemistry of the fine suspended load in rivers, with particular emphasis on the inorganic colloidal fraction exported to the ocean. We measured REE and Nd isotopic compositions in different size-fractions of river suspended particulates collected in the Murray-Darling Basin (MDB), the largest river system in Australia. For comparison, we also analyzed detrital sediments extracted from a nearby marine sediment core, which provides a record of the MDB river discharge. As will be discussed below, our new results provide evidence that volcanogenic material is overrepresented in the finest suspended particulate fractions exported from river systems to the oceans.

\section{MATERIALS AND METHODS}

\section{Geological Background of the Murray-Darling Basin}

The Murray-Darling Basin covers an area of about $1.1 \times 10^{6} \mathrm{~km}^{2}$, ranging from about $25^{\circ} \mathrm{S}$ to $38^{\circ} \mathrm{S}$. It is composed of two main rivers: the Darling River (and its tributaries) in the northern part of the basin and the River Murray (and its tributaries) in the southern part of the watershed (Figure 1). Both rivers merge at Wentworth before eventually reaching the sea. The Darling watershed mostly drains Mesozoic and Cenozoic sedimentary formations, together with widespread Permian and Tertiary volcanics associated with the New England Fold Belt (Figure 1B). In contrast, the Murray catchment is dominated by Palaeozoic plutonic and metasedimentary rocks from the Lachlan Fold Belt (Figure 1B), also including localized greenstone belts and a suite of various mafic and felsic volcanic rocks (Kingham, 1998; Gingele and De Deckker, 2005a). The southern part of the River Murray watershed also drains Tertiary basalts from the Newer Volcanic Province (Figure 1B). The lithological composition of Darling and Murray river sub-basins was extracted from the GLiM global lithological map database (Hartmann and Moosdorf, 2012), showing that both river basins are dominated by sedimentary rocks (93 and $86 \%$, respectively; Table 1). Volcanic rocks account for about $4 \%$ of the Darling River watershed (mainly corresponding to basic and intermediate volcanic rocks), and $~ 5 \%$ in the Murray catchment (mostly acid rocks). Compared to other major river systems worldwide, the MDB is characterized by a very low average gradient $(<1 \mathrm{~m} / \mathrm{km})$ and correspondingly an extremely low annual sediment load (1 Mt/yr; Milliman and Farnsworth, 2011). Due to its small suspended particle concentration and overall low topographical relief, much of the sediment entering the MDB river network at present is deposited within flood plains, commonly in transient storage prior to entering the ocean (De Rose et al., 2004).

\section{Suspended River Particulates and Marine Sediment Core}

A series of suspended river particulates from the MDB were analyzed for $\mathrm{Nd}$ isotopes during the course of this project (Figure 1A; Table 2). This includes two samples collected near the confluence point of the River Murray (at Merbein) and the Darling River (at Pomona). Two other samples were also collected in the Murray watershed: in the upstream portion of the River Murray (at Corowa), and in the Ovens River (a leftbank tributary of the Murray, which flows from the Victorian Alps) (Figure 1A). The sampling and filtration procedures for suspended river particles have been described previously (Douglas et al., 1995; Dosseto et al., 2006). Briefly, large volumes of river water (about $100 \mathrm{~L}$ ) were transferred into a polyethylene container. Soon after collection $(1 \mathrm{~h})$, the suspended sediment load was split into separate grain-size fractions using sieving ( $>25 \mu \mathrm{m}$; i.e., the coarse silt particulate fraction), continuous flow centrifugation (1-25 $\mu \mathrm{m}$; i.e., the fine silt particulate fraction), and tangential flow filtration, for extracting fine clays $(1-0.2 \mu \mathrm{m})$ and colloids $(0.2-0.006 \mu \mathrm{m} ; 0.006-0.003 \mu \mathrm{m})$. 

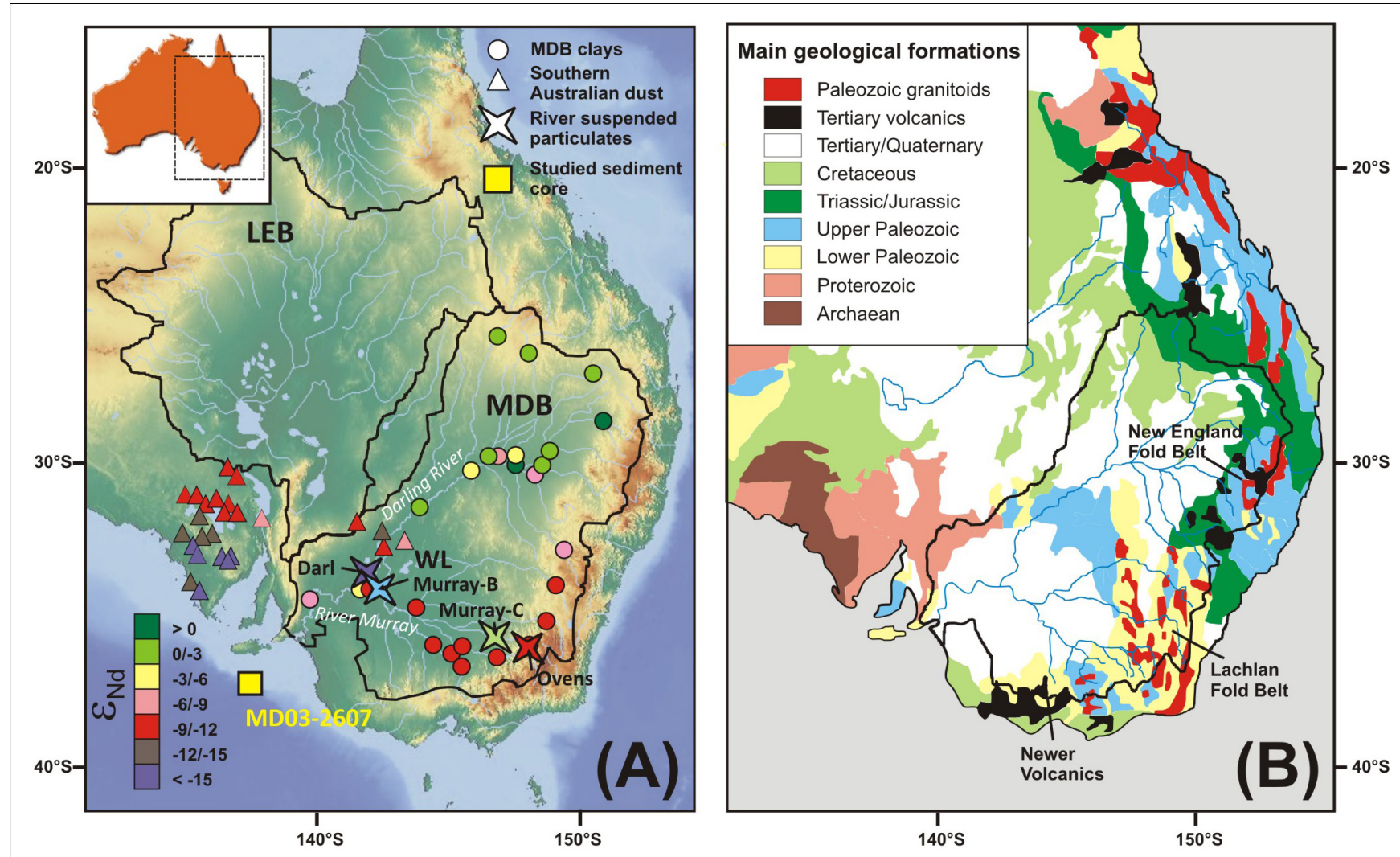

FIGURE 1 | (A) Location of studied river particulate samples in the Murray-Darling Basin (MDB) and marine sediment core MD03-2607. The range of neodymium isotopic compositions ( $\left.\varepsilon_{\mathrm{Nd}}\right)$ for MDB suspended particulates (stars) and clay-size fractions (Gingele and De Deckker, 2005a; circles), and southern Australian dust sources (De Deckker et al., 2014; De Deckker, 2019; triangles) are also represented. LEB refers to Lake Eyre Basin. (B) Simplified geological map of Southeast Australia (redrawn from Palfreyman et al., 1976).

TABLE 1 | Lithological composition of the Darling and Murray catchments (\%).

\begin{tabular}{|c|c|c|c|c|c|c|c|c|c|c|c|c|c|c|c|c|}
\hline \multirow[t]{2}{*}{ River basin } & \multirow[t]{2}{*}{$\begin{array}{c}\text { Metam. } \\
\text { rocks }\end{array}$} & \multicolumn{3}{|c|}{$\begin{array}{l}\text { Plutonic } \\
\text { rocks }\end{array}$} & \multirow[t]{2}{*}{$\begin{array}{l}\text { Total Metam. } \\
\text { + Pluton. }\end{array}$} & \multicolumn{4}{|c|}{$\begin{array}{l}\text { Volcanic } \\
\text { rocks }\end{array}$} & \multirow[t]{2}{*}{$\begin{array}{l}\text { Total } \\
\text { Volc. }\end{array}$} & \multicolumn{5}{|c|}{$\begin{array}{l}\text { Sedimentary } \\
\text { rocks }\end{array}$} & \multirow[t]{2}{*}{$\begin{array}{l}\text { Total } \\
\text { Sedim. }\end{array}$} \\
\hline & & Acid & Basic & Interm & & Acid & Basic & Interm. & Pyrocl. & & Silicicl. & Unconsol. & Carb. & Mixed. & Evap. & \\
\hline Darling Murray & 0.5 & 2.0 & 0.1 & 0.1 & 3 & 0.9 & 1.7 & 1.3 & 0.0 & 4 & 13.1 & 63.0 & 0.1 & 17.2 & 0.0 & 97 \\
\hline River Murray & 0.9 & 7.7 & 0.1 & 0.1 & 9 & 2.9 & 1.0 & 1.0 & 0.0 & 5 & 9.9 & 63.9 & 0.0 & 11.6 & 0.5 & 90 \\
\hline
\end{tabular}

Note that these colloidal fractions are also commonly referred to as "dissolved," as opposed to the $<0.003 \mu \mathrm{m}$ fraction ( $1 \mathrm{kDa}$ ), which corresponds to the "truly" dissolved load in rivers.

Marine sediment core MD03-2607 ( $36^{\circ} 58^{\prime} \mathrm{S}, 137^{\circ} 24^{\prime} \mathrm{E} ; \sim 33 \mathrm{~m}$ long) was recovered at $865 \mathrm{~m}$ water depth on a platform from the Murray Canyons Group region, in a highly productive area located today about $200 \mathrm{~km}$ offshore the end point of the MDB (Figure 1A). The core is composed of foraminiferal silty sands intercalated with silty clay sections, with total carbonate contents up to $\sim 90 \mathrm{wt} \%$ (Gingele and De Deckker, 2005a). Core MD03-2607 provides a continuous record of sediment export and environmental changes from the MDB during the last two glacial/interglacial cycles (viz. $250 \mathrm{kyr}$ ) (Gingele et al., 2004; Gingele and De Deckker, 2005a; Lopes dos Santos et al., 2013; Bayon et al., 2017; De Deckker et al., 2019). During glacial periods and associated sea-level lowstands of the Late Quaternary, the River Murray discharged directly at the edge of the continental shelf, resulting in enhanced delivery of terrigenous sediment to the Murray Canyons area (Gingele et al., 2004). In this study, we chose specifically to analyze sediments deposited during sea-level lowstands, when detrital sedimentation at site MD032607 was dominated by river inputs from the MDB (Bayon et al., 2017). A total of 24 samples were analyzed from two sediment intervals: (1) between $210-390 \mathrm{~cm}$ depth $(\sim 19-28 \mathrm{kyr}$ BP; i.e., the Last Glacial Maximum); (2) between 810 and $870 \mathrm{~cm}$ depth ( $\sim 60-70 \mathrm{kyr}$ BP; i.e., Marine Isotope Stage MIS 4$)$. For comparison, a series of copepod fecal pellet separates $(n=4)$ from MD03-2607 were also hand-picked under a binocular microscope from various sediment layers in core for both REE and $\mathrm{Nd}$ isotopic measurements. 
TABLE 2 | Rare earth element and Nd isotopic composition for size fractions of river suspended particulates.

\begin{tabular}{|c|c|c|c|c|c|c|c|c|c|c|c|c|c|c|c|c|c|c|c|c|c|}
\hline Grain-size $(\mu \mathrm{m})$ & ${ }^{143} \mathrm{Nd} /{ }^{144} \mathrm{Nd}^{\mathrm{a}}$ & $\varepsilon N d$ & $\mathbf{Y}$ & $\mathrm{La}^{\mathrm{b}}$ & $\mathrm{Ce}$ & $\operatorname{Pr}$ & Nd & Sm & $\mathrm{Eu}$ & Gd & Tb & Dy & Ho & $\mathrm{Er}$ & $\mathrm{Tm}$ & $\mathrm{Yb}$ & Lu & $(\mathrm{Nd} / \mathrm{Yb})_{\mathrm{N}}{ }^{\mathrm{c}}$ & $\mathrm{Ce} / \mathrm{Ce}^{\star}$ & $\mathrm{Eu} / \mathrm{Eu}^{*}$ & Y/Ho \\
\hline$>25$ & 0.512173 & $-8.9 \pm 0.2$ & 17.58 & 24.12 & 46.80 & 5.20 & 19.67 & 4.20 & 0.77 & 3.13 & 0.52 & 3.00 & 0.58 & 1.60 & 0.20 & 1.44 & 0.23 & 1.26 & 1.03 & 0.98 & 30.4 \\
\hline $25-1$ & 0.512084 & $-10.7 \pm 0.2$ & 21.49 & 27.89 & 61.53 & 6.83 & 26.23 & 5.30 & 1.04 & 3.96 & 0.64 & 3.60 & 0.70 & 1.87 & 0.24 & 1.71 & 0.27 & 1.41 & 1.05 & 1.05 & 30.5 \\
\hline $1-0.2$ & 0.512196 & $-8.5 \pm 0.2$ & 35.17 & 33.17 & 70.20 & 8.89 & 34.97 & 7.50 & 1.56 & 5.60 & 0.98 & 5.88 & 1.17 & 3.34 & 0.41 & 2.97 & 0.46 & 1.08 & 0.94 & 1.08 & 30.1 \\
\hline $0.2-.006$ & 0.512195 & $-8.5 \pm 0.2$ & 19.54 & 18.09 & 34.67 & 4.66 & 18.58 & 4.20 & 0.87 & 3.05 & 0.55 & 3.36 & 0.67 & 1.87 & 0.23 & 1.62 & 0.26 & 1.06 & 0.90 & 1.07 & 29.3 \\
\hline $0.006-.003$ & 0.512259 & $-7.2 \pm 0.2$ & 8.89 & 5.13 & 9.45 & 1.41 & 5.79 & 1.40 & 0.33 & 1.07 & 0.21 & 1.32 & 0.29 & 0.86 & 0.11 & 0.76 & 0.13 & 0.71 & 0.83 & 1.16 & 30.7 \\
\hline \multicolumn{22}{|c|}{ River murray (Corowa) } \\
\hline$>25$ & 0.512018 & $-11.9 \pm 0.2$ & 22.47 & 31.66 & 68.47 & 7.59 & 27.32 & 5.70 & 1.04 & 4.20 & 0.68 & 3.72 & 0.70 & 2.01 & 0.25 & 1.71 & 0.27 & 1.47 & 0.98 & 0.98 & 31.9 \\
\hline $25-1$ & 0.512068 & $-11.0 \pm 0.2$ & 30.28 & 39.20 & 85.80 & 9.54 & 34.97 & 7.20 & 1.47 & 5.36 & 0.89 & 5.04 & 0.97 & 2.67 & 0.33 & 2.43 & 0.38 & 1.33 & 1.00 & 1.09 & 31.3 \\
\hline $1-0.2$ & 0.512173 & $-8.9 \pm 0.2$ & 41.03 & 34.68 & 65.87 & 8.56 & 33.88 & 7.40 & 1.65 & 5.93 & 1.07 & 6.36 & 1.27 & 3.61 & 0.46 & 3.24 & 0.52 & 0.96 & 0.92 & 1.12 & 32.3 \\
\hline $0.2-0.006$ & 0.512149 & $-9.4 \pm 0.2$ & 20.52 & 14.32 & 26.87 & 3.58 & 14.21 & 3.30 & 0.73 & 2.55 & 0.54 & 2.88 & 0.58 & 1.74 & 0.21 & 1.53 & 0.26 & 0.86 & 0.90 & 1.06 & 35.5 \\
\hline $0.006-0.003$ & 0.512186 & $-8.7 \pm 0.2$ & 9.87 & 5.80 & 10.40 & 1.41 & 6.01 & 1.40 & 0.34 & 1.07 & 0.20 & 1.26 & 0.28 & 0.80 & 0.10 & 0.75 & 0.13 & 0.74 & 0.95 & 1.23 & 35.7 \\
\hline \multicolumn{22}{|l|}{ Darling river } \\
\hline$>25$ & 0.512406 & $-4.4 \pm 0.2$ & 20.52 & 21.86 & 49.40 & 5.53 & 21.86 & 4.50 & 0.95 & 3.38 & 0.57 & 3.36 & 0.67 & 1.87 & 0.24 & 1.71 & 0.26 & 1.18 & 1.07 & 1.11 & 30.8 \\
\hline $25-1$ & 0.512446 & $-3.6 \pm 0.2$ & 23.45 & 27.14 & 61.53 & 7.05 & 26.23 & 5.50 & 1.21 & 3.87 & 0.66 & 3.72 & 0.74 & 2.01 & 0.26 & 1.89 & 0.29 & 1.28 & 0.98 & 1.18 & 31.6 \\
\hline $1-0.2$ & 0.512517 & $-2.2 \pm 0.2$ & 22.47 & 23.37 & 52.00 & 6.18 & 24.04 & 5.10 & 1.21 & 3.63 & 0.63 & 3.60 & 0.70 & 1.87 & 0.25 & 1.80 & 0.28 & 1.23 & 0.99 & 1.26 & 31.9 \\
\hline $0.2-0.006$ & 0.512476 & $-3.0 \pm 0.2$ & 23.45 & 24.12 & 54.60 & 6.72 & 26.23 & 5.70 & 1.30 & 3.87 & 0.69 & 3.96 & 0.77 & 2.14 & 0.26 & 1.89 & 0.30 & 1.28 & 0.96 & 1.22 & 30.6 \\
\hline $0.006-0.003$ & 0.512361 & $-5.2 \pm 0.2$ & 3.81 & 3.02 & 5.46 & 0.74 & 3.06 & 0.67 & 0.19 & 0.49 & 0.09 & 0.56 & 0.11 & 0.35 & 0.05 & 0.31 & 0.06 & 0.92 & 0.93 & 1.47 & 33.6 \\
\hline \multicolumn{22}{|l|}{ Ovens river } \\
\hline$>25$ & 0.512046 & $-11.5 \pm 0.2$ & 23.45 & 42.97 & 92.73 & 10.08 & 36.06 & 7.20 & 1.04 & 4.86 & 0.76 & 3.96 & 0.75 & 2.01 & 0.25 & 1.80 & 0.28 & 1.84 & 1.00 & 0.81 & 31.1 \\
\hline $25-1$ & 0.512079 & $-10.9 \pm 0.2$ & 27.35 & 42.97 & 92.73 & 10.08 & 36.06 & 7.30 & 1.21 & 4.86 & 0.81 & 4.44 & 0.84 & 2.27 & 0.28 & 1.98 & 0.32 & 1.68 & 1.00 & 0.91 & 32.4 \\
\hline $1-0.2$ & 0.512215 & $-8.2 \pm 0.2$ & 41.03 & 39.20 & 92.73 & 10.19 & 39.34 & 8.30 & 1.56 & 6.02 & 1.07 & 6.36 & 1.26 & 3.48 & 0.44 & 3.15 & 0.51 & 1.15 & 1.06 & 0.98 & 32.6 \\
\hline $0.2-0.006$ & 0.512207 & $-8.4 \pm 0.2$ & 15.63 & 11.31 & 24.27 & 3.04 & 12.02 & 2.60 & 0.55 & 1.98 & 0.36 & 2.28 & 0.45 & 1.32 & 0.17 & 1.26 & 0.21 & 0.88 & 0.96 & 1.09 & 34.5 \\
\hline $0.006-0.003$ & 0.512447 & $-3.7 \pm 0.2$ & 12.70 & & 12.13 & 1.63 & 7.10 & 1.60 & 0.43 & 1.24 & 0.24 & 1.56 & 0.34 & 1.06 & 0.14 & 1.08 & 0.18 & 0.61 & 0.99 & 1.35 & 37.4 \\
\hline WRAS & & & 29.40 & 37.80 & 77.69 & 8.77 & 32.69 & 6.15 & 1.19 & 5.19 & 0.82 & 4.95 & 1.02 & 2.97 & - & 3.01 & 0.456 & & & & \\
\hline
\end{tabular}

${ }^{a}$ Nd isotopic compositions are from this study. ${ }^{b}$ REE concentrations are from Douglas (1993) and Douglas et al. (1999). ${ }^{c}$ Normalized to World River Average Silt (WRAS; Bayon et al., 2015). 


\section{Chemical Preparations and Analytical Procedures}

Separated size-fractions of river suspended particulates were dissolved using $\mathrm{HF}-\mathrm{HNO}_{3}-\mathrm{HClO}_{4}$ digestion. Neodymium was purified by ion chromatography following the method of Korsch and Gulson (1986), and analyzed at the Center for Isotope Studies at CSIRO North Ryde using a VG354S thermal ionization mass spectrometer (TIMS). Total procedural blanks (between 250 and $350 \mathrm{pg} / \mathrm{g}$ ) represented less than $0.2 \%$ contribution to the analyzed samples. Mass bias corrections on $\mathrm{Nd}$ were made with the exponential law, using ${ }^{146} \mathrm{Nd} /{ }^{144} \mathrm{Nd}=0.7219$, and ${ }^{143} \mathrm{Nd} /{ }^{144} \mathrm{Nd}$ corrected values were normalized to the La Jolla value of ${ }^{143} \mathrm{Nd} /{ }^{144} \mathrm{Nd}=0.511858$ (Lugmair et al., 1983). Repeated analyses of a La Jolla standard solution during the measurement sessions of this study gave ${ }^{143} \mathrm{Nd} /{ }^{144} \mathrm{Nd}$ of $0.511849 \pm 0.000010$ (2 SD; $n=4)$, hence corresponding to an external reproducibility of $\sim \pm 0.20 \varepsilon$ (2 SD).

Following the procedure of Bayon et al. (2002), both marine sediment and fecal pellet samples from MD03-2607 were treated successively with acetic acid (AA), mixed AA -hydroxylamine hydrochloride $(\mathrm{HH})$, and hydrogen peroxide solutions to quantitatively remove all carbonate, Fe-Mn oxyhydroxide and organic components, respectively. For marine sediments, fine-grained fractions $(<4 \mu \mathrm{m})$ were separated from the residual detritus by centrifugation (Bayon et al., 2015) and digested by alkaline fusion (Bayon et al., 2009), whereas detrital fractions separated from fecal pellets were digested with HF-HCl. Two samples of $<4 \mu \mathrm{m}$ detrital sediment from MD03-2607 (from 250 to $860 \mathrm{~cm}$ core depth) were analyzed by X-ray diffractometry at IFREMER (Bruker D8 Advance) for mineralogical characterization. Rare earth element concentrations in MD03-2607 clay-rich fractions and fecal pellets were determined on a Thermo Fisher Scientific Quad X-Series 2 (Royal Museum for Central Africa; Tervuren, Belgium) and Thermo Fisher Scientific Element 2 (Vrije Universiteit Brussel; Belgium) ICP-MS, respectively. Polyatomic oxide and hydroxide interferences for the REE were corrected using oxide formation rates determined from the analysis of $\mathrm{Ba}+\mathrm{Ce}, \mathrm{Pr}+\mathrm{Nd}$ and $\mathrm{Sm}+\mathrm{Eu}+\mathrm{Gd}+\mathrm{Tb}$ solutions. The REE abundances were determined using the $\mathrm{Tm}$ addition method with a precision better than 5\% (Barrat et al., 1996; Bayon et al., 2009). Neodymium isotopic measurements on fecal pellet separates were performed at the Pôle Spectrométrie Océan (Brest, France) using a Thermo Fisher Scientific Neptune multi-collector ICPMS, after $\mathrm{Nd}$ purification by ion exchange chromatography (Bayon et al., 2012). Note that $\mathrm{Nd}$ isotopic data for the fine-grained $(<4 \mu \mathrm{m})$ detrital sediment in core MD03-2607 were already reported in Bayon et al. (2017), as part of a study that aimed at reconstructing the evolution of sediment provenance during the last glacial period and its link to past hydroclimatic changes in southeast Australia. Due to small sample size (typically just a few $\mathrm{mg}$ ), the in-run analytical uncertainties associated with $\mathrm{Nd}$ isotopic measurements of copepod fecal pellets were generally larger (from \pm 0.2 to $0.7 \varepsilon ; 2$ se) than the external reproducibility determined from repeated analyses of the JNd-i solution $( \pm 0.12 \varepsilon$; $2 \mathrm{SD} ; n=5)$. Note also that all REE abundances reported in this study are normalized to World River Average Silt (WRAS; Bayon et al., 2015; Table 2), and all epsilon $\mathrm{Nd}$ values $\left(\varepsilon_{\mathrm{Nd}}\right)$ are calculated using ${ }^{143} \mathrm{Nd} /{ }^{144} \mathrm{Nd}=0.512630$ (Bouvier et al., 2008). The Ce and Eu enrichment or depletion in studied samples were quantified using WRAS-normalized $\mathrm{Ce}$ and Eu anomalies, respectively; calculated as follows: Ce/Ce* $=\mathrm{C} \varepsilon_{\mathrm{N}} /\left[\operatorname{Pr}_{\mathrm{N}}{ }^{*}\left(\operatorname{Pr}_{\mathrm{N}} / \mathrm{Nd}_{\mathrm{N}}\right)\right]$, and $\mathrm{Eu} / \mathrm{Eu}^{*}=\mathrm{Eu}_{\mathrm{N}} /\left(\mathrm{Sm}_{\mathrm{N}}{ }^{2 *} \mathrm{~Tb}_{\mathrm{N}}\right)^{1 / 3}$ (Lawrence et al., 2006). Estimated errors on calculated $\mathrm{Ce}$ - and $\mathrm{Eu}$-anomalies are about $10 \%$.

\section{Background Information on REE in Suspended River Particulates From the Murray-Darling Basin}

Rare earth element abundances for the same set of river suspended particulate samples investigated during this study were partially published and briefly discussed in previous studies (Douglas, 1993; Douglas et al., 1995; Douglas et al., 1999) that examined changes in strontium ( $\mathrm{Sr}$ ) isotope signatures as a function of grain size. These REE results are compiled in Table 2 and illustrated in Figure 2; and are briefly summarized below. Note that these analyses were performed on bulk (unleached) suspended loads, so that measured REE concentrations, while being mostly controlled by detrital silicate sources, can be also affected to some extent by the presence of labile Fe-Mn oxyhydroxide phases and organic compounds (Douglas et al., 1999; Leybourne and Johannesson, 2008). To a large extent, this explains why the finest size fractions, which may contain a substantial fraction of organic colloids (Douglas et al., 1999) are characterized by lower REE abundances (Figure 2A). Therefore, in order to remove any dilution effect, shale-normalized REE patterns are also reported as normalized to $\mathrm{Nd}$ (Figure 2B), using the WRAS value for $\mathrm{Nd}$ (32.69 ppm). Except for the finest colloids $(0.006-0.003 \mu \mathrm{m})$, all size-fractions separated from the Darling River sample display similar WRAS-normalized REE patterns, characterized by light and heavy REE (LREE and HREE, respectively) depletion relative to mid REE (MREE). All three samples from the Murray River watershed display similar size-specific REE patterns, with: (1) silt-size fractions ( $>25 \mu \mathrm{m} ; 25-1 \mu \mathrm{m}$ ) being characterized by pronounced HREE depletion; (2) clay-size fractions $(1-0.2 \mu \mathrm{m})$ displaying relatively flat WRAS-normalized patterns; and (3) colloidal-size fractions $(0.2-0.006 \mu \mathrm{m} ; 0.006-0.003 \mu \mathrm{m})$ being generally characterized by much lower REE abundances, the presence of both positive and negative Eu- and Ce- anomalies, respectively, and a LREE depletion relative to MREE and HREE (Figure 2; Table 2).

\section{RESULTS}

\section{Nd Isotopes in Suspended River Particulates}

Except for the finest colloids $(0.006-0.003 \mu \mathrm{m})$, different sizefractions transported by the Darling River display similar $\varepsilon_{\mathrm{Nd}}$ $(-3.3 \pm 0.9 ; 1 \mathrm{SD})$, WRAS-normalized $\mathrm{Nd} / \mathrm{Yb}$ ratios or $(\mathrm{Nd} / \mathrm{Yb})_{\mathrm{N}}$ $(1.24 \pm 0.05 ; 1 \mathrm{SD})$ values, characterized by the absence of Ceanomalies (Ce/Ce* $\sim 1.0$ ) (Table 2; Figure 3). In contrast, river suspended materials in the Murray watershed display systematic 


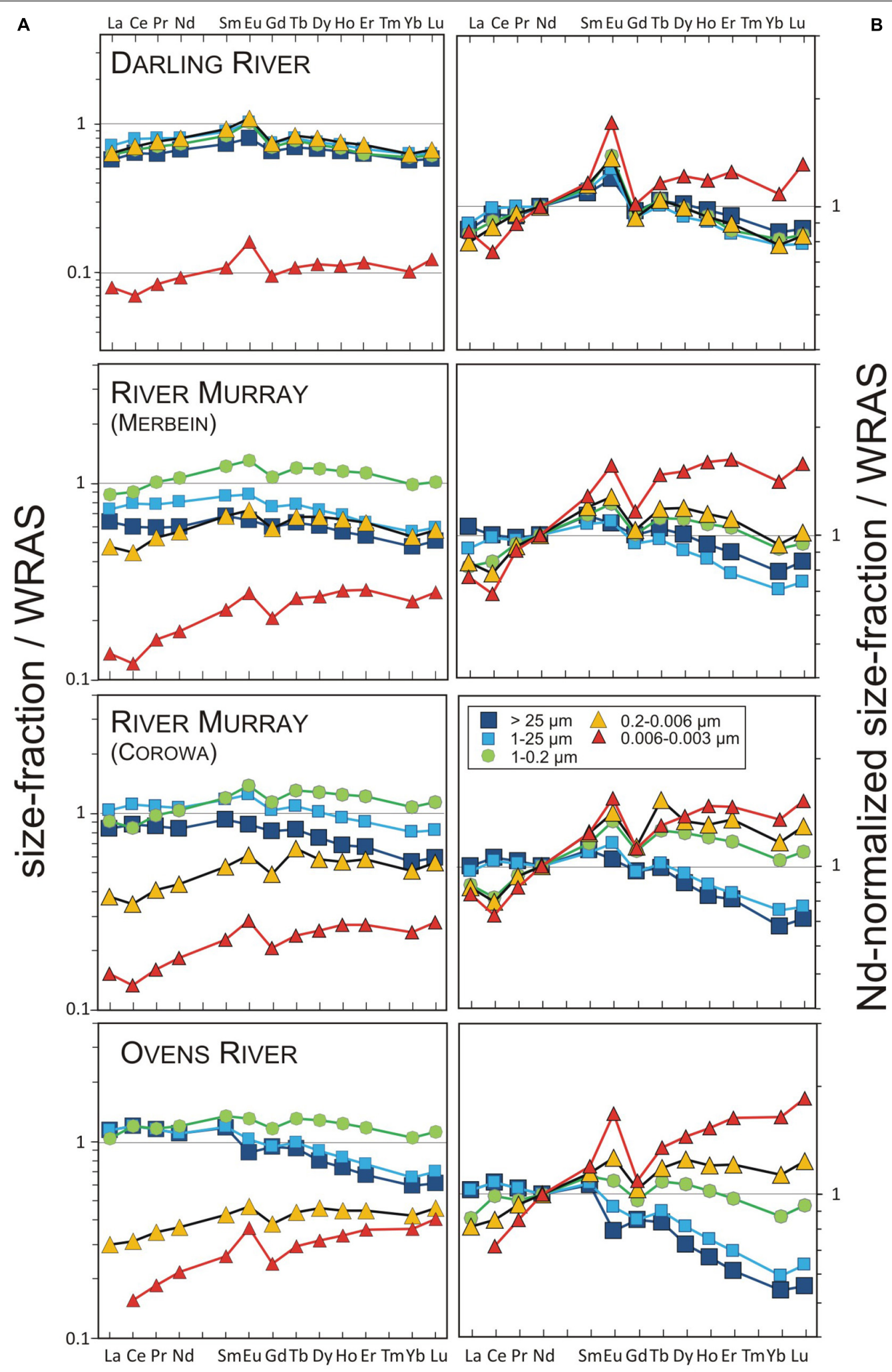

FIGURE 2 | (A) Rare earth element abundances of size-fractions from river suspended material in the Murray-Darlin Basin (Douglas, 1993; Douglas et al., 1999) normalized to World River Average Silt (WRAS; Bayon et al., 2015). (B) WRAS-normalized REE abundances normalized to the NdwRAS. The different size-fractions

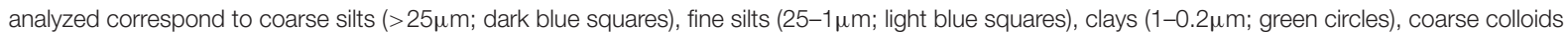
$(0.2-0.006 \mu \mathrm{m}$; orange triangles), and fine colloids $(0.006-0.003 \mu \mathrm{m}$; red triangles). 

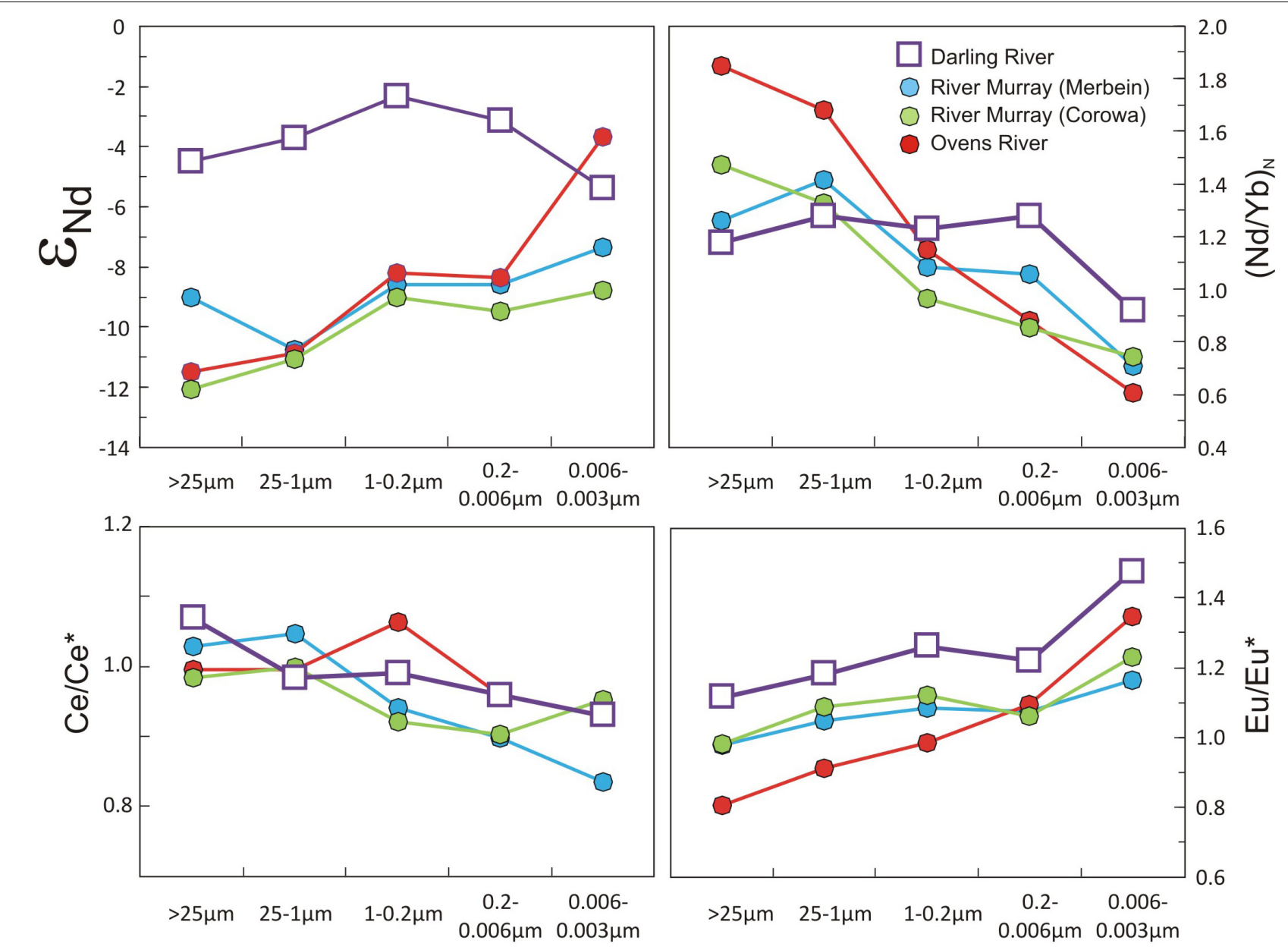

FIGURE 3 | Size-dependent variability of Nd isotope, WRAS-normalized $\mathrm{Nd} / \mathrm{Yb}$ ratios $(\mathrm{Nd} / \mathrm{Yb})_{\mathrm{N}}$, and cerium- (Ce/Ce*) and europium- (Eu/Eu*) anomalies in river suspended material from the Murray-Darling Basin. Grain-size fractions from River Murray and Ovens River suspended particulates illustrate the effect of grain-size on $\mathrm{Nd}$ isotopic compositions and REE abundances.

size-dependent geochemical variability. As grain-size decreases, the $\mathrm{Nd}$ isotopic composition evolves toward more radiogenic (higher $\varepsilon_{\mathrm{Nd}}$ ) values, with differences of up to eight epsilon units for the case of the Ovens River (from -11.5 to -3.7 , from coarse silts to fine colloids, respectively; Table 2 ). In contrast, $\mathrm{Ce} / \mathrm{Ce}^{*}$ and $(\mathrm{Nd} / \mathrm{Yb})_{\mathrm{N}}$ values progressively decrease with decreasing grain-size in river suspended loads from the Murray watershed, with the largest variation being also observed in the Ovens River (Figure 3). At all studied locations, Eu-anomalies display a trend toward positive $\left(\mathrm{Eu} / \mathrm{Eu}^{*}\right)$ values with decreasing grain-size (up to 1.5 for the finest colloidal fractions).

\section{Marine Sediment and Fecal Pellets From Core MD03-2607}

The mineralogical composition for the fine-grained detrital fractions separated from core MD03-2607 is dominated by clays and/or micas (75\%), with minor amounts of quartz, plagioclase and K-feldspar (Table 3). Overall, fine-grained fractions from core MD03-2607 display REE patterns similar to those for
River Murray and Darling River clays (Figure 4A), but are characterized by small negative Ce-anomalies (with an average value of $0.86 \pm 0.02$; Table 4 ) and positive Eu-anomalies (1.12 \pm 0.02; Table 4), respectively. The detrital fractions extracted from fecal pellets exhibit similar WRAS-normalized REE patterns, but with much lower abundances (Figure 4A; Table 5). To a large extent, these low abundances simply reflect the fact that measured concentrations for pellets are reported over initial sample weight (i.e., prior to leaching), due to the small sample size analyzed (typically $<10 \mathrm{mg}$ ), and not relative to the mass of the detrital silicate fraction analyzed. When normalized to Nd to remove any dilution effect, the WRAS-normalized REE patterns for studied fecal pellets and marine sediment samples match relatively well with the range of REE patterns for clay$(1-0.2 \mu \mathrm{m})$ and colloidal size fractions of suspended loads from the MDB (Figure 4B). The $\mathrm{Nd}$ isotopic composition of the detrital fraction of fecal pellets ranges from $\varepsilon_{\mathrm{Nd}} \sim-6.0$ to -8.8 , being slightly shifted toward more negative $\varepsilon_{\mathrm{Nd}}$ values (from $\sim$ 0.6 to 1.6 epsilon units) compared to corresponding clay-size detrital fractions (Table 5). 
TABLE 3 | Mineralogical composition of fine-grained detrital fractions (core MD03-2607).

\begin{tabular}{|c|c|c|c|c|c|c|c|}
\hline Sample & Age (kyrBP) & Clays-micas (\%) & Quartz (\%) & Plagioclase (\%) & K-Feldspar (\%) & Mg-Calcite (\%) & Calcite Aragonite (\%) (\%) \\
\hline $250 \mathrm{~cm}$ & 20.4 & 75 & 10 & 8 & 7 & - & - \\
\hline $860 \mathrm{~cm}$ & 67.9 & 74 & 8 & 9 & 8 & - & - \\
\hline
\end{tabular}

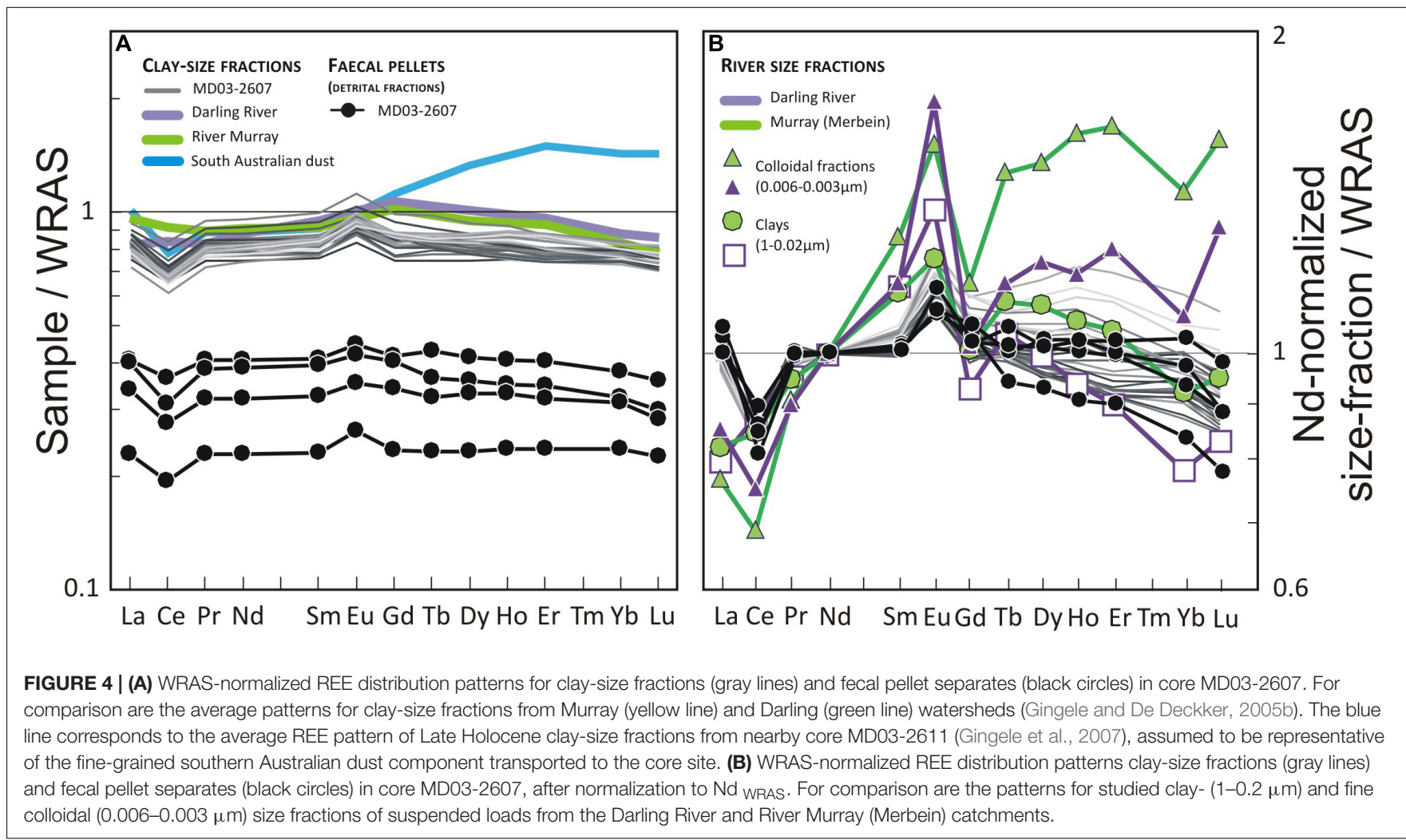

\section{DISCUSSION}

\section{Factors Controlling Size-Dependent Nd Isotopic Decoupling in the Murray-Darling River System}

As for $\mathrm{Nd}$ isotopes, Douglas et al. (1995) reported significant size-dependent variability for strontium isotopes in the same river suspended material from the Murray watershed. Similarly, the largest $\mathrm{Sr}$ isotopic variations between silt- and colloidal size fractions were observed in the Ovens River (from ${ }^{87} \mathrm{Sr} /{ }^{86} \mathrm{Sr}$ $\sim 0.760$ to 0.718 , respectively) and the Murray River at Merbein (from $\sim 0.748$ to 0.718 ), indicating a trend toward lower $\mathrm{Sr}$ isotopic signatures with decreasing grain-size. Douglas and collaborators argued that much of the $\mathrm{Sr}$ signal associated with river colloids in the MDB was derived from the river's dissolved load, being complexed or adsorbed onto organic matter (Douglas et al., 1995; Douglas et al., 1999). They also suggested that the lower $\mathrm{Sr}$ isotopic ratios and associated positive $\mathrm{Eu}$ anomalies in the fine particulate material from the Murray catchment area reflected preferential dissolution of plagioclase during incongruent weathering of granitic rocks. However, plagioclase are characterized by relatively low $\mathrm{Sm} / \mathrm{Nd}$ ratios [see
Figure 2 of Bayon et al. (2006)], which lead with time and radioactive decay of ${ }^{147} \mathrm{Sm}$ to ${ }^{143} \mathrm{Nd}$ to unradiogenic (low) $\mathrm{Nd}$ isotopic signatures compared to bulk rock $\varepsilon_{\mathrm{Nd}}$ compositions (Aubert et al., 2001). Hence, plagioclase and other Na-Ca-rich feldspars are probably unlikely to entirely account for the large size-dependent $\mathrm{Nd}$ isotopic variability observed in MDB rivers. Alternatively, other mineral phases could possibly play a role in controlling the distribution of $\mathrm{Nd}$ isotopes in the MDB river suspended material. For example, a recent investigation of Indus River sediments led to the suggestion that $\mathrm{Nd}$ isotopic differences between medium sand and silt-size fractions could reflect preferential sorting of micas versus REE-bearing accessory minerals (e.g., allanite, monazite), respectively (Jonell et al., 2018). Another study conducted in a small granitic watershed of the Vosges mountains (France) also reported particularly high ${ }^{143} \mathrm{Nd} /{ }^{144} \mathrm{Nd}$ signatures in river suspended material compared to corresponding source rocks (Aubert et al., 2001); a finding that was attributed to preferential erosion and export of finegrained apatite. By analogy, preferential sorting of accessory trace minerals such as apatite and/or allanite in the fine suspended material transported by MDB rivers could possibly explain, at least to some extent, the observed trend toward higher $\varepsilon_{\mathrm{Nd}}$ values with decreasing grain-size. 
TABLE 4 | Rare earth element and Nd isotopic composition of fine-grained $(<4 \mu \mathrm{m})$ detrital fractions (core MD03-2607).

\begin{tabular}{|c|c|c|c|c|c|c|c|c|c|c|c|c|c|c|c|c|c|c|c|c|}
\hline Depth (cm) & Age (kyrBP) & $\varepsilon_{N d^{a}}$ & $Y^{b}$ & La & $\mathrm{Ce}$ & $\mathrm{Pr}$ & $\mathrm{Nd}$ & $\mathrm{Sm}$ & $\mathrm{Eu}$ & Gd & Tb & Dy & Ho & $\mathrm{Er}$ & $\mathrm{Yb}$ & Lu & $(\mathrm{Nd} / \mathrm{Yb})_{\mathrm{N}}$ & $\mathrm{Ce} / \mathrm{Ce}^{\star}$ & $\mathrm{Eu} / \mathrm{Eu}^{*}$ & $\mathrm{Y} / \mathrm{Ho}$ \\
\hline 210 & 19.06 & -6.26 & 22.89 & 29.04 & 52.05 & 6.72 & 25.25 & 4.78 & 1.04 & 3.97 & 0.64 & 3.85 & 0.81 & 2.29 & 2.34 & 0.34 & 0.99 & 0.88 & 1.12 & 28.1 \\
\hline 220 & 19.38 & -6.55 & 23.02 & 29.65 & 53.04 & 6.88 & 25.72 & 4.82 & 1.06 & 4.01 & 0.65 & 3.90 & 0.82 & 2.32 & 2.35 & 0.34 & 1.01 & 0.87 & 1.13 & 28.2 \\
\hline 230 & 19.71 & -6.33 & 22.24 & 28.55 & 50.78 & 6.56 & 24.41 & 4.68 & 0.99 & 3.87 & 0.61 & 3.69 & 0.77 & 2.21 & 2.25 & 0.33 & 1.00 & 0.87 & 1.10 & 29.0 \\
\hline 240 & 20.03 & -6.26 & 23.92 & 30.78 & 55.01 & 7.11 & 26.43 & 5.18 & 1.07 & 4.25 & 0.67 & 3.95 & 0.81 & 2.37 & 2.37 & 0.34 & 1.03 & 0.87 & 1.08 & 29.4 \\
\hline 250 & 20.37 & -6.72 & 24.23 & 31.61 & 56.29 & 7.30 & 27.19 & 5.18 & 1.09 & 4.27 & 0.68 & 4.01 & 0.82 & 2.36 & 2.38 & 0.34 & 1.05 & 0.87 & 1.09 & 29.6 \\
\hline 260 & 20.71 & -6.46 & 26.53 & 34.20 & 61.97 & 7.97 & 29.98 & 5.84 & 1.24 & 4.91 & 0.75 & 4.37 & 0.88 & 2.49 & 2.43 & 0.35 & 1.14 & 0.88 & 1.11 & 30.1 \\
\hline 270 & 21.17 & -6.69 & 27.96 & 35.34 & 65.28 & 8.35 & 31.43 & 6.15 & 1.33 & 5.17 & 0.80 & 4.63 & 0.94 & 2.61 & 2.52 & 0.37 & 1.15 & 0.89 & 1.13 & 29.8 \\
\hline 280 & 21.63 & -6.87 & 24.76 & 33.27 & 57.96 & 7.71 & 28.71 & 5.59 & 1.16 & 4.53 & 0.71 & 4.15 & 0.84 & 2.39 & 2.41 & 0.34 & 1.10 & 0.85 & 1.10 & 29.4 \\
\hline 290 & 21.94 & -6.89 & 24.47 & 32.22 & 56.14 & 7.43 & 27.73 & 5.30 & 1.11 & 4.39 & 0.70 & 4.00 & 0.82 & 2.33 & 2.35 & 0.34 & 1.08 & 0.85 & 1.09 & 29.7 \\
\hline 300 & 22.24 & -6.92 & 24.36 & 31.97 & 55.78 & 7.44 & 27.95 & 5.37 & 1.13 & 4.46 & 0.70 & 4.07 & 0.83 & 2.35 & 2.40 & 0.34 & 1.07 & 0.85 & 1.10 & 29.2 \\
\hline 310 & 22.72 & -6.69 & 24.00 & 31.36 & 54.21 & 7.22 & 26.69 & 5.09 & 1.07 & 4.26 & 0.68 & 4.00 & 0.82 & 2.34 & 2.40 & 0.34 & 1.02 & 0.84 & 1.09 & 29.4 \\
\hline 320 & 23.21 & -7.12 & 23.68 & 31.32 & 54.12 & 7.14 & 26.42 & 5.01 & 1.05 & 4.18 & 0.66 & 3.90 & 0.78 & 2.23 & 2.31 & 0.34 & 1.05 & 0.85 & 1.09 & 30.2 \\
\hline 330 & 23.69 & -7.09 & 25.01 & 32.34 & 55.63 & 7.43 & 27.64 & 5.37 & 1.13 & 4.47 & 0.69 & 4.09 & 0.82 & 2.32 & 2.36 & 0.35 & 1.08 & 0.84 & 1.11 & 30.6 \\
\hline 340 & 24.17 & -6.80 & 24.55 & 31.76 & 55.01 & 7.30 & 27.08 & 5.26 & 1.13 & 4.45 & 0.68 & 4.01 & 0.81 & 2.28 & 2.30 & 0.34 & 1.08 & 0.85 & 1.12 & 30.4 \\
\hline 350 & 24.66 & -6.90 & 25.60 & 32.94 & 55.81 & 7.44 & 27.62 & 5.24 & 1.13 & 4.40 & 0.70 & 4.16 & 0.83 & 2.37 & 2.40 & 0.34 & 1.06 & 0.84 & 1.11 & 30.7 \\
\hline 360 & 25.14 & -7.19 & 23.85 & 31.81 & 53.67 & 7.22 & 27.06 & 5.14 & 1.11 & 4.59 & 0.67 & 3.92 & 0.79 & 2.25 & 2.25 & 0.32 & 1.11 & 0.84 & 1.13 & 30.1 \\
\hline 370 & 26.68 & -7.51 & 22.83 & 31.71 & 52.52 & 7.19 & 26.45 & 5.00 & 1.08 & 4.48 & 0.66 & 3.84 & 0.77 & 2.20 & 2.20 & 0.32 & 1.11 & 0.81 & 1.12 & 29.6 \\
\hline 380 & 28.22 & -7.68 & 23.31 & 32.28 & 53.19 & 7.27 & 26.55 & 5.00 & 1.08 & 4.49 & 0.66 & 3.86 & 0.78 & 2.20 & 2.23 & 0.32 & 1.09 & 0.81 & 1.12 & 30.1 \\
\hline 810 & 60.43 & -5.57 & 29.57 & 30.32 & 53.12 & 7.06 & 26.84 & 5.27 & 1.19 & 4.50 & 0.72 & 4.33 & 0.89 & 2.53 & 2.41 & 0.35 & 1.02 & 0.87 & 1.16 & 33.2 \\
\hline 820 & 61.93 & -5.44 & 30.89 & 29.96 & 52.95 & 6.95 & 26.34 & 5.20 & 1.18 & 4.62 & 0.72 & 4.37 & 0.90 & 2.55 & 2.42 & 0.35 & 1.00 & 0.87 & 1.16 & 34.1 \\
\hline 840 & 64.92 & -5.34 & 31.45 & 28.84 & 51.32 & 6.70 & 25.38 & 5.08 & 1.14 & 4.56 & 0.71 & 4.36 & 0.91 & 2.60 & 2.49 & 0.37 & 0.94 & 0.88 & 1.15 & 34.5 \\
\hline 850 & 66.42 & -5.40 & 28.42 & 29.58 & 52.48 & 6.84 & 26.11 & 5.18 & 1.13 & 4.46 & 0.69 & 4.14 & 0.86 & 2.38 & 2.31 & 0.34 & 1.04 & 0.89 & 1.13 & 33.0 \\
\hline 860 & 67.92 & -5.74 & 27.84 & 29.68 & 51.91 & 6.86 & 26.02 & 5.05 & 1.12 & 4.50 & 0.69 & 4.15 & 0.85 & 2.40 & 2.32 & 0.33 & 1.03 & 0.87 & 1.13 & 32.7 \\
\hline 870 & 69.42 & -6.38 & 31.16 & 29.66 & 50.43 & 6.71 & 25.39 & 4.94 & 1.10 & 4.57 & 0.70 & 4.25 & 0.89 & 2.58 & 2.43 & 0.36 & 0.96 & 0.86 & 1.13 & 34.8 \\
\hline
\end{tabular}

${ }^{a} \mathrm{Nd}$ isotopic compositions $(\varepsilon N d \pm 0.17)$ are from Bayon et al. (2017). ${ }^{b} R E E$ concentrations are from this study. 
TABLE 5 | Rare earth element and Nd isotopic composition of fecal pellet separates (core MD03-2607).

\begin{tabular}{|c|c|c|c|c|c|c|c|c|c|c|c|c|c|c|c|c|c|c|c|c|c|}
\hline Sample & $\begin{array}{l}{ }^{143} \mathrm{Nd} / \\
{ }^{144} \mathrm{Nd}\end{array}$ & $\varepsilon_{\text {Nd PELLET }}$ & $\begin{array}{l}\varepsilon_{\mathrm{Nd}} \\
\text { CLAY }\end{array}$ & $\mathbf{Y}$ & La & $\mathrm{Ce}$ & $\mathrm{Pr}$ & $\mathrm{Nd}$ & $\mathrm{Sm}$ & $\mathrm{Eu}$ & Gd & Tb & Dy & Ho & $\mathrm{Er}$ & $\mathrm{Yb}$ & Lu & $\begin{array}{l}(\mathrm{Nd} / \\
\mathrm{Yb})_{\mathrm{N}}\end{array}$ & $\begin{array}{l}\mathrm{Ce} / \\
\mathrm{Ce}^{\star}\end{array}$ & $\begin{array}{l}\mathrm{Eu/} \\
\mathrm{Eu}^{*}\end{array}$ & $\begin{array}{l}\text { Y/ } \\
\text { Ho }\end{array}$ \\
\hline $260 \mathrm{~cm}$ & 0.512230 & $-7.93 \pm 0.19$ & -6.46 & 12.48 & 15.36 & 28.13 & 3.56 & 13.25 & 2.52 & 0.53 & 2.15 & 0.35 & 2.03 & 0.41 & 1.20 & 1.14 & 0.16 & 1.07 & 0.89 & 1.07 & 30.1 \\
\hline $310 \mathrm{~cm}$ & 0.512209 & $-8.33 \pm 0.24$ & -6.69 & 10.55 & 15.09 & 24.17 & 3.36 & 12.60 & 2.42 & 0.50 & 2.08 & 0.30 & 1.77 & 0.36 & 1.03 & 0.97 & 0.14 & 1.20 & 0.79 & 1.10 & 29.7 \\
\hline $380 \mathrm{~cm}$ & 0.512185 & $-8.80 \pm 0.23$ & -7.68 & 10.02 & 12.83 & 21.41 & 2.81 & 10.49 & 2.00 & 0.42 & 1.77 & 0.26 & 1.64 & 0.34 & 0.95 & 0.94 & 0.13 & 1.03 & 0.83 & 1.08 & 29.8 \\
\hline $850 \mathrm{~cm}$ & 0.512326 & $-6.05 \pm 0.65$ & -5.40 & 7.34 & 8.65 & 15.01 & 2.00 & 7.47 & 1.41 & 0.31 & 1.22 & 0.19 & 1.15 & 0.24 & 0.70 & 0.71 & 0.10 & 0.97 & 0.84 & 1.14 & 30.6 \\
\hline
\end{tabular}

Similarly, the grain-size dependency of $\mathrm{Nd}$ isotopes in suspended river material could also reflect increasing contribution of volcanogenic particles in the finest sediment fractions. This is because all geologically recent volcanic rocks such as SE Australian Tertiary basalts are typically characterized by distinctive radiogenic (high $\varepsilon_{\mathrm{Nd}}$ ) $\mathrm{Nd}$ isotopic signatures (e.g., McDonough et al., 1985; Martin and McCulloch, 1999). Various geochemical investigations have already suggested that erosion processes could induce preferential sorting of volcanogenic material into the fine-grained sediment fractions compared to material derived from other source rocks (McLennan et al., 1989; Garçon and Chauvel, 2014; Bayon et al., 2015). To some extent, this effect relates to evidence that weathering of volcanic rocks is commonly associated with formation of soils containing high proportions of amorphous or poorly crystalline clays and colloids (Dahlgren et al., 2004). The Murray catchment area is dominated by Palaeozoic granitoids and marine metasedimentary rocks, but also includes localized outcrops of volcanic rocks in the southern and eastern part of the watershed, which could act as a source of volcanogenic particles in the river suspended load. This hypothesis is well supported by the evidence that all size-fractions from studied river particulate samples plot on the $\mathrm{Sr}-\mathrm{Nd}$ isotope array defined by all rocks, soils and river sediment samples in the Murray-Darling Basin (McDonough et al., 1985; Martin and McCulloch, 1999; Gingele and De Deckker, 2005a), which altogether can be interpreted, to a first approximation, as a general mixing trend between SE Australian Tertiary basalts, and Palaeozoic granitoids and metasedimentary rocks (Figure 5). The specific behavior of REE during alteration of these particular basalts has been the subject of previous dedicated works (Price et al., 1991; Martin and McCulloch, 1999). In SE Australia, basalt weathering leads to formation of neoformed clay minerals, such as allophane, montmorillonite (smectite) and kaolinite. Interestingly, results obtained on weathered rock outcrops and basaltic soils showed that basalt alteration is accompanied by development of a pronounced negative Ce anomaly in weathered products (Price et al., 1991; Martin and McCulloch, 1999). As proposed previously (Prudêncio et al., 1995), the development of Ce-anomalies during weathering of SE Australian basalts is thought to relate to the fact that $\mathrm{Ce}$ is partially oxidized during basalt weathering and preferentially sequestered in upper soil sequences relative to its neighbored trivalent REE. This process would then result in the development of negative $\mathrm{Ce}$-anomalies in weathering products formed in lower soil profiles. In previous studies, the occurrence of negative Ce-anomalies in river water "dissolved" material (commonly referred to as $<0.2 \mu \mathrm{m}$, but which may also include colloids) has been commonly attributed to preferential oxidation of $\mathrm{C}^{4+}$ onto $\mathrm{Fe}-\mathrm{Mn}$ oxyhydroxide phases (e.g., Goldstein and Jacobsen, 1988b). However, we suggest here that the occurrence of negative $\mathrm{Ce}$-anomalies in the fine size fractions of suspended material from the MBD mainly reflects a volcanogenic signature. Taken together, the observed trends toward negative Ce-anomaly, positive Eu-anomaly (i.e., another typical characteristic of sediments derived from volcanic provinces; McDonough et al., 1985; Martin and McCulloch, 1999; Bayon et al., 2015) and more radiogenic $\mathrm{Nd}$ isotopic compositions with decreasing grain-size, collectively point toward a strong imprint of volcanogenic material in controlling the $\mathrm{Nd}$ isotopic composition of the fine clay and colloidal-size fractions in watersheds.

In order to provide quantitative estimates for the presence of volcanogenic material in the fine-grained suspended loads transported in the River Murray watershed, we used a simple two end-member mixing model that considers both $\mathrm{Nd}$ isotopes $\left(\varepsilon_{\mathrm{Nd}}\right)$ and $\mathrm{Eu} / \mathrm{Eu}^{*}$ anomalies. The coarse-grained $(>25 \mu \mathrm{m})$ fractions of the suspended loads were assumed to be representative of the local "granitoid" end-member in each of the studied subcatchments of the River Murray. Additionally, a "volcanic" endmember was determined using a compilation of REE and $\mathrm{Nd}$ isotopic data for various basalts and basaltic soils from the Darling River basin (Martin and McCulloch, 1999) and the Newer Volcanics in SE Australia (McDonough et al., 1985), both characterized by radiogenic $\varepsilon_{\mathrm{Nd}}$ values and pronounced Euanomalies $\left(\mathrm{Eu} / \mathrm{Eu}^{*}>1.4\right)$. The studied size-fractions from the River Murray suspended loads are well aligned on the resulting mixing lines (Figure 6), which can hence be used to graphically estimate the relative percentage contribution of volcanogenic material in each size-fraction. To a first approximation, this suggests that volcanogenic particles represent approximately $10 \%, 20 \%$ and between $30-60 \%$ of the $25-1 \mu \mathrm{m}, 1-0.006 \mu \mathrm{m}$, and $0.006-0.003 \mu \mathrm{m}$ size-fractions, respectively.

\section{Preferential Export of Fine Volcanogenic Particles to the Nearby South-Eastern Australian Ocean Margin}

The findings inferred above from the analysis of river suspended particulates suggest that volcanogenic material may be preferentially exported from the MDB together with the finegrained sediment load that enters the ocean. We can evaluate this hypothesis by comparing REE data for core MD03-2607 with results obtained for river suspended material (see above) and average compositions for clay-size fractions of the Darling River, the River Murray, and dust-source regions from southern 


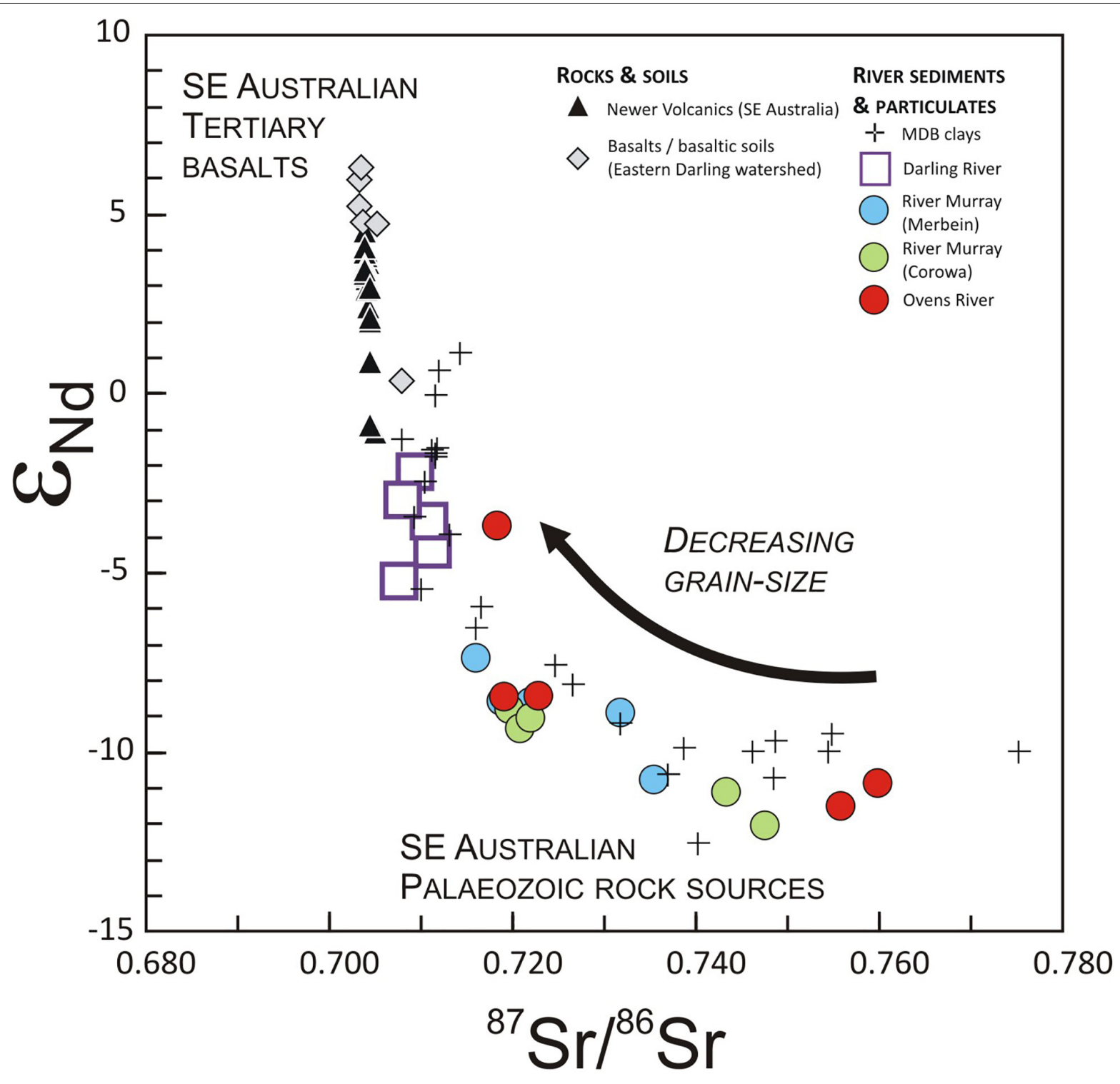

FIGURE 5 $\left.\right|^{143} \mathrm{Nd} /{ }^{144} \mathrm{Nd}$ (expressed as $\varepsilon_{\mathrm{Nd}}$ ) versus ${ }^{87} \mathrm{Sr} /{ }^{86} \mathrm{Sr}$ variation for the grain-size fractions separated from river suspended matter in the Murray-Darling Basin (MDB). Also shown for comparison are renormalized Sr-Nd data for various basaltic rocks and soils (McDonough et al., 1985; Martin and McCulloch, 1999) and clay-size fractions from the MDB (Gingele and De Deckker, 2005b). All grain-size fractions plot on the general mixing trend defined by SE Australian Tertiary basalts and Palaeozoic granitoids and metasedimentary rocks, suggesting that the finest size-fractions in river suspended particulates incorporate higher contribution of volcanogenic material.

Australian; i.e., the main potential contributors of fine-grained sediments to the SE Australian margin (Figure 4A). Compared to these three end-members, the $<4 \mu \mathrm{m}$ detrital fractions isolated from core MD03-2607 display particular REE characteristics, such as negative Ce-anomalies, slightly positive Eu-anomalies and the absence of LREE enrichment over HREE, which, taken together, share strong similarities with the geochemical composition of fine-grained particles transported by MDB rivers (Figure 4B).

In marine sediments, the occurrence of negative Ce-anomalies generally relate to the presence of seawater-derived mineral phases. While all carbonate, Fe-Mn oxyhydroxide and organic components have been selectively removed by sequential leaching prior to analysis (as confirmed by our mineralogical data; Table 3), the presence of residual marine precipitates such as barite (i.e., a resistant mineral that is typically found in marine sediments underlying highly productive surface waters) could also possibly explain the observed REE patterns for MD032607 detrital fractions. In this study, our fine-grained detrital fractions display $\mathrm{Ba}$ abundances $(289 \pm 15 \mathrm{ppm}$; data not shown here) that fall within the lower range of concentrations reported for clay-size fractions in large river sediments worldwide (380 \pm 104 ppm; Bayon et al., 2015), hence suggesting negligible amounts of marine barite at the studied site. In addition, Y/Ho, 


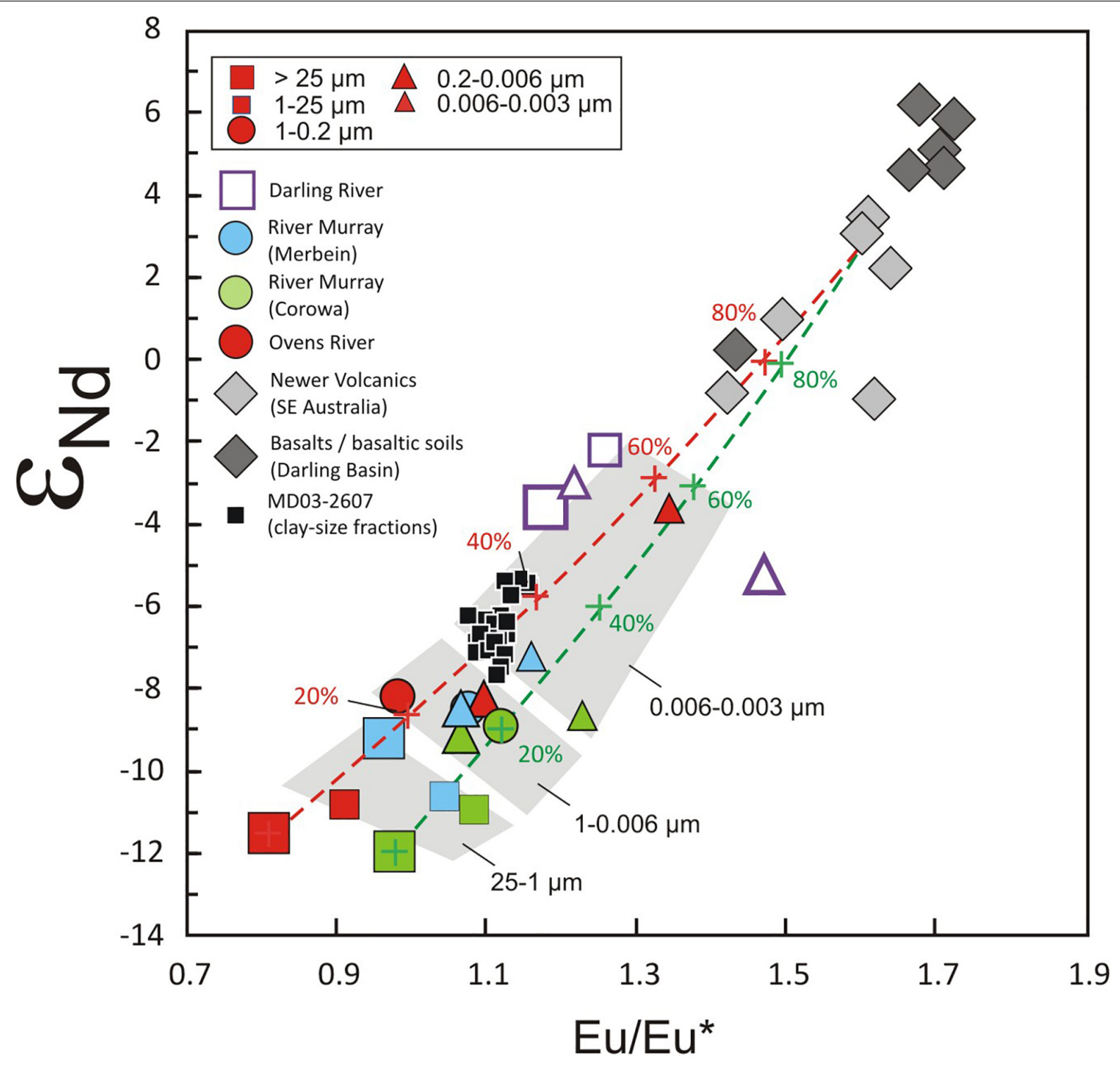

FIGURE 6 | Relationships between ${ }^{143} \mathrm{Nd} /{ }^{144} \mathrm{Nd}$ (expressed as $\varepsilon_{\mathrm{Nd}}$ ) and Eu-anomalies (Eu/Eu ${ }^{*}$ ) in rocks, soils and suspended particulates from the Murray-Darling Basin, and inferred mixing model between Paleozoic granitoid and Tertiary volcanic sediment sources. The coarse-grained (>25 $\mu \mathrm{m})$ fractions of the suspended loads were assumed to be representative of the local "granitoid" end-member in each of the studied sub-catchments of the River Murray. The "volcanic" end-member was determined using a compilation of REE and Nd isotopic data for various basalts and basaltic soils from the Darling River basin (Martin and McCulloch, 1999) and the Newer Volcanics in SE Australia (McDonough et al., 1985). The dotted lines correspond to the resulting mixing lines that are used to graphically estimate the relative percentage contribution of volcanogenic material in each size-fraction. Also shown are the data for the studied marine sediment samples.

i.e., another useful proxy for the relative contribution of seawater versus terrestrial signatures in marine sediments (Nozaki et al., 1997) displays values (30.7 \pm 1.9 ; Table 4) indistinguishable from detrital clay-size river sediments worldwide $(30.5 \pm 1.0$; Bayon et al., 2015). Therefore, we are confident that the particular REE features displayed by MD03-2607 fine-grained detrital fractions cannot be explained by the presence of marine precipitates. Instead, and by analogy with results obtained on our series of river suspended particulates, we propose that all above-mentioned geochemical characteristics mainly reflect the presence of abundant volcanogenic particles in the fine-grained detrital fractions extracted from core MD03-2607. Using the same two end-member mixing model discussed above (Figure 6), we can estimate graphically that volcanogenic material accounts for about $30-40 \%$ of the fine-detrital sediment exported from the MDB during the last glacial periods.

\section{Implications on the Potential Fertilizing Role of Volcanogenic Particles on Marine Productivity}

During past glacial periods (MIS 2 and 4), the Murray Canyons were directly connected to the mouth of the River Murray due 
to sea-level regression (see Figure 3 in Hill et al., 2009), and site MD03-2607 was most likely directly under the influence of freshwater discharge from the MBD. Presumably, the deposition of fine-grained particles at site MD03-2607 during these periods partially resulted from salt-induced coagulation of colloidal particles exported from the MDB upon mixing with seawater. Estuarine processes are known to be associated with quantitative removal of river-borne colloids with major impact on the distribution of trace metals in the water column (Sholkovitz, 1992; Sholkovitz and Szymczak, 2000; Rousseau et al., 2015; Tepe and Bau, 2016). Such processes can lead to removal of up to $~ 95 \%$ of colloidal REE in the low-salinity zone of estuaries, followed by subsequent release in the mid-salinity region (e.g., Rousseau et al., 2015). In addition, recycling of colloids by plankton in surface waters (e.g., Tranvik et al., 1993), and subsequent deposition as aggregates through the water column, could also account for the presence of small-size volcanogenic particles at site MD032607. This mechanism is supported by our data on fecal pellet separates, which display the same negative $\mathrm{Ce}$ - and positive $\mathrm{Eu}$ - anomalies typical of the MDB river-borne fine volcanogenic particles (Figure 4). Fecal pellets are produced by zooplankton activity in high productivity surface waters, and their vertical settling in the water column is likely to result in substantial export of fine inorganic particles to underlying sediments.

In this study, the evidence that about $30-40 \%$ of the finegrained sediment exported to the southeast Australian margin is of volcanic origin (despite originating from a catchment where volcanic rocks only totalize a few percent of the total watershed) could have implications for marine productivity. The fertilizing potential of volcanogenic particles in ocean surface waters is well documented (e.g., Frogner et al., 2001; Jones and Gislason, 2008; Achterberg et al., 2013; Tepe and Bau, 2014). Exposure of volcanic ash and other fine volcanogenic material to seawater is expected to introduce large amounts of labile phosphate and other bioactive elements such as iron, leading in turn to enhanced marine primary productivity (e.g., Achterberg et al., 2013). In addition to the well-studied examples of ocean fertilization following episodic fallouts of volcanic ash (Olgun et al., 2011; Hoffmann et al., 2012), we speculate that sustained export of fine-grained volcanogenic colloidal particles from river systems worldwide could possibly represent a previously unrecognized source of fertilizing trace metals and nutrients to ocean margins.

\section{CONCLUSION AND PERSPECTIVES}

The data presented in this study have demonstrated significant size-dependent $\mathrm{Nd}$ isotopic variability in the river suspended material transported in the Murray-Darling Basin. The decoupling of $\mathrm{Nd}$ isotopes and $\mathrm{REE}$ can account for large $\varepsilon_{\mathrm{Nd}}$ differences (up to 8 units) between size-fractions ranging from coarse silts $(>25 \mu \mathrm{m})$ to fine colloids $(<0.2 \mu \mathrm{m})$, which are best explained by increasing contribution of volcanogenic particles as grain-size decreases. This result has important implications since it suggests that river discharge may be accompanied by preferential export of fine volcanogenic particles to the ocean. In the particular context of the Murray-Darling
Basin, characterized by very low river sediment discharge, the imprint of volcanogenic sediment associated with export of fine particles has been shown to influence the distribution of REE and $\mathrm{Nd}$ isotopes in nearby marine sediments.

This study highlights the interest for further developing the application of radiogenic isotopes and trace elements to sizespecific sediment analyses in environmental studies. In particular, the utility of colloidal fractions in sediments underlying highly productive areas, as potential archives for both natural and anthropogenic sources of nanoparticles exported by rivers should be explored in more details. Further studies should also aim at investigating the potential fertilizing impact of preferential export of volcanogenic particles on marine productivity.

\section{DATA AVAILABILITY STATEMENT}

All datasets generated for this study are included in the article/supplementary material.

\section{AUTHOR CONTRIBUTIONS}

GB, GBD, and PD contributed to the conception and design of the study. GJD and GB performed $\mathrm{Nd}$ isotopic compositions of suspended river particulates and fecal pellets, respectively. GB and LM conducted chemical preparation and trace element measurements of marine sediments, respectively. GB, GBD, and PD wrote the manuscript.

\section{FUNDING}

GB was supported by an IEF Marie Curie fellowship (Grant No. FP7-PEOPLE-2012-IEF 327778). This study also received internal funding from the CSIRO Land and Water.

\section{ACKNOWLEDGMENTS}

This paper is dedicated to the memory of Geoff N. Denton, a former MSc student at the Macquarie University (Sydney), who initiated $\mathrm{Nd}$ isotopic work on the river suspended material from the Murray-Darling Basin. We thank the crews of R/V Marion Dufresne, especially Yvon Balut, and all participants of the AUSCAN cruise (MD131; PI: P.D.D.) for their assistance at sea. We are most grateful to Mrs. Judith Shelley (ANU), who extracted the fecal pellets from the core sediments, to Thibault Lambert (Univ. of Lausanne), who provided lithological data, to Sandrine Chéron for XRD analyses, and to Emmanuel Ponzevera for assistance during MC-ICPMS measurements. Finally, we acknowledge Johan Schijf for editorial handling, Matthew Leybourne, Brian Haley and Torben Stichel for providing insightful comments that significantly help to improve the manuscript. 


\section{REFERENCES}

Achterberg, E. P., Moore, C. M., Henson, S. A., Steigenberger, S., Stohl, A., Eckhardt, S., et al. (2013). Natural iron fertilization by the Eyjafjallajökull volcanic eruption. Geophys. Res. Lett. 40, 921-926. doi: 10.1002/grl.50221

Andersson, P. S., Dahlqvist, R., Ingri, J., and Gustafsson, Ö. (2001). The isotopic composition of $\mathrm{Nd}$ in a boreal river: a reflection of selective weathering and colloidal transport. Geochim. Cosmochim. Acta 65, 521-527. doi: 10.1016/ S0016-7037(00)00535-4

Aubert, D., Stille, P., and Probst, A. (2001). REE fractionation during granite weathering and removal by waters and suspended loads: $\mathrm{Sr}$ and $\mathrm{Nd}$ isotopic evidence. Geochim. Cosmochim. Acta 65, 387-406. doi: 10.1016/S0016-7037(00) 00546-9

Barrat, J. A., Keller, F., Amossé, J., Taylor, R. N., Nesbitt, R. W., and Hirata, T. (1996). Determination of rare earth elements in sixteen silicate reference samples by ICP-MS after Tm addition and ion exchange separation. Geostand. Newsletter 20, 133-139. doi: 10.1111/j.1751-908X.1996.tb00177.x

Bayon, G., Barrat, J. A., Etoubleau, J., Benoit, M., Bollinger, C., and Revillon, S. (2009). Determination of rare earth elements, Sc, Y, Zr, Ba, Hf and Th in geological samples by ICP-MS after Tm addition and alkaline fusion. Geostand. Geoanal. Res. 33, 51-62. doi: 10.1111/j.1751-908X.2008.00880.x

Bayon, G., De Deckker, P., Magee, J. W., Germain, Y., Bermell, S., Tachikawa, K., et al. (2017). Extensive wet episodes in Late Glacial Australia resulting from high-latitude forcings. Sci. Rep. 7:44054. doi: 10.1038/srep4405

Bayon, G., Dennielou, B., Etoubleau, J., Ponzevera, E., Toucanne, S., and Bermell, S. (2012). Intensifying weathering and land use in Iron Age Central Africa. Science 335, 1219-1222. doi: $10.1126 /$ science. 1215400

Bayon, G., German, C. R., Boella, R. M., Milton, J. A., Taylor, R. N., and Nesbitt, R. W. (2002). An improved method for extracting marine sediment fractions and its application to $\mathrm{Sr}$ and Nd isotopic analysis. Chem. Geol. 187, 179-199. doi: 10.1016/s0009-2541(01)00416-8

Bayon, G., Toucanne, S., Skonieczny, C., André, L., Bermell, S., Cheron, S., et al. (2015). Rare earth elements and neodymium isotopes in world river sediments revisited. Geochim. Cosmochim. Acta 170, 17-38. doi: 10.1016/j.gca.2015.08.001

Bayon, G., Vigier, N., Burton, K. W., Brenot, A., Carignan, J., Etoubleau, J., et al. (2006). The control of weathering processes on riverine and seawater hafnium isotope ratios. Geology 34, 433-436. doi: 10.1130/G22130.1

Bouchez, J., Gaillardet, J., France-Lanord, C., Maurice, L., and Dutra-Maia, P. (2011). Grain size control of river suspended sediment geochemistry: clues from Amazon River depth profiles. Geochem. Geophys. Geosyst. 12:Q03008. doi: 10.1029/2010GC003380

Bouvier, A., Vervoort, J. D., and Patchett, P. J. (2008). The Lu-Hf and Sm-Nd isotopic composition of CHUR: constraints from unequilibrated chondrites and implications for the bulk composition of terrestrial planets. Earth Planet. Sci. Lett. 273, 48-57. doi: 10.1016/j.epsl.2008.06.010

Brito, P., Prego, R., Mil-Homens, M., Caçador, I., and Caetano, M. (2018). Sources and distribution of yttrium and rare earth elements in surface sediments from Tagus estuary, Portugal. Sci. Total Environ. 621, 317-325. doi: 10.1016/ j.scitotenv.2017.11.245

Dahlgren, R. A., Saigusa, M., and Ugolini, F. C. (2004). The nature, properties and management of volcanic soils. Adv. Agronom. 82, 113-182. doi: 10.1371/journal. pone. 0198517

Dausmann, V., Gutjahr, M., Frank, M., Kouzmanov, K., and Schaltegger, U. (2019). Experimental evidence for mineral-controlled release of radiogenic $\mathrm{Nd}$, $\mathrm{Hf}$ and $\mathrm{Pb}$ isotopes from granitic rocks during progressive chemical weathering. Chem. Geol. 507, 64-84. doi: 10.1016/j.chemgeo.2018.12.024

De Deckker, P. (2019). An evaluation of Australia as a major source of dust. Earth Sci. Rev. 194, 536-567. doi: 10.1016/j.earscirev.2019.01.008

De Deckker, P., Arnold, L., van der Kaars, S., Bayon, G., Stuut, J. B., Perner, K., et al. (2019). Marine Isotope Stage 4 in Australasia: a full glacial culminating 65,000 years ago - global connections and implications for human dispersal. Quat. Sci. Rev. 204, 187-207. doi: 10.1016/j.quascirev.2018.11.017

De Deckker, P., Munday, C. I., Brocks, J., O'Loingsigh, T., Allison, G. E., Hope, J., et al. (2014). Characterisation of the major dust storm that traversed over eastern Australia in September 2009; a multidisciplinary approach. Aeolian Res. 15, 133-149. doi: 10.1016/j.aeolia.2014. 07.003

De Rose, R., Prosser, I., and Weisse, M. (2004). "Patterns of erosion and sediment transport in the Murray-darling basin," in Sediment Transfer Through the
Fluvial System, Book Series, Vol. 288, eds V. Golosov, V. Belyaev, and D. E. Walling, (Wallingford: IAHS), 245-252.

Dosseto, A., Turner, S. P., and Douglas, G. B. (2006). Uranium-series isotopes in colloids and suspended sediments: timescale for sediment production and transport in the Murray-Darling River system. Earth Planet. Sci. Lett. 246, 418-431. doi: 10.1016/j.epsl.2006.04.019

Douglas, G. B. (1993). Characterization of Suspended Particulate Matter in the Murray-Darling River System. Ph.D. dissertation, Monash University, Melbourne.

Douglas, G. B., Gray, C. M., Hart, B. T., and Beckett, R. A. (1995). A strontium isotopic investigation of the origin of suspended particulate matter from the Murray-Darling River system, Australia. Geochim. Cosmochim. Acta 59, 37993815. doi: 10.1016/0016-7037(95)00266-3

Douglas, G. B., Hart, B. T., Beckett, R. A., Gray, C. M., and Oliver, R. L. (1999). Geochemistry of suspended particulate matter (SPM) in the Murray-Darling River system: a conceptual isotopic/geochemical model for the fractionation of major, trace and rare earth elements. Aquat. Geochem. 5, 167-194. doi: 10.1023/A:1009632310689

Frogner, P., Gíslason, S. R., and Óskarsson, N. (2001). Fertilizing potential of volcanic ash in ocean surface water. Geology 29, 487-490.

Gaillardet, J., Dupré, B., and Allègre, C. J. (1999). Geochemistry of large river suspended sediments: silicate weathering or recycling tracer? Geochim. Cosmochim. Acta 63, 4037-4051. doi: 10.1016/S0016-7037(99)00307-5

Garçon, M., and Chauvel, C. (2014). Where is basalt in river sediments, and why does it matter? Earth Planet. Sci. Lett. 407, 61-69. doi: 10.1016/j.epsl.2014. 09.033

Garzanti, E., Andó, S., France-Lanord, C., Censi, P., Vignola, P., Galy, V., et al. (2011). Mineralogical and chemical variability of fluvial sediments 2 . Suspended-load silt (Ganga-Brahmaputra, Bangladesh). Earth Planet. Sci. Lett. 302, 107-120. doi: 10.1016/j.epsl.2010.11.043

Garzanti, E., Andò, S., and Vezzoli, G. (2009). Grain-size dependence of sediment composition and environmental bias in provenance studies. Earth Planet. Sci. Lett. 277, 422-432. doi: 10.1016/j.epsl.2008.11.007

Gibbs, R. J. (1967). The geochemistry of the Amazon River system: part I. The factors that control the salinity and the composition and concentration of the suspended solids. Geol. Soc. Am. Bull. 78, 1203-1232.

Gingele, F. X., and De Deckker, P. (2005a). Clay mineral, geochemical and $\mathrm{Sr}-\mathrm{Nd}$ isotopic fingerprinting of sediments in the Murray-Darling fluvial system, southeast Australia. Aust. J. Earth Sci. 52, 965-974. doi: 10.1080/ 08120090500302301

Gingele, F. X., and De Deckker, P. (2005b). Late quaternary fluctuations of palaeoproductivity in the Murray Canyons area, South Australian continental margin. Palaeogeogr. Palaeoclimatol. Palaeoecol. 220, 361-373. doi: 10.1016/j. palaeo.2005.01.012

Gingele, F. X., De Deckker, P., and Hillenbrand, C. D. (2004). Late Quaternary terrigenous sediments from the Murray Canyons area, offshore South Australia and their implications for sea level change, palaeoclimate and palaeodrainage of the Murray-Darling Basin. Mar. Geol. 212, 183-197. doi: 10.1016/j.margeo. 2004.09.001

Gingele, F. X., De Deckker, P., and Norman, M. (2007). Late Pleistocene and Holocene climate of SE Australia reconstructed from dust and river loads deposited offshore the River Murray mouth. Earth Planet. Sci. Lett. 255, 257272. doi: 10.1016/j.epsl.2006.12.019

Goldstein, S. J., and Jacobsen, S. B. (1988a). Nd and Sr isotopic systematics of river water suspended material: implications for crustal evolution. Earth Planet. Sci. Lett. 87, 249-265. doi: 10.1016/0012-821X(88)90013-1

Goldstein, S. J., and Jacobsen, S. B. (1988b). Rare earth elements in river waters. Earth Planet. Sci. Lett. 89, 35-47. doi: 10.1016/0012-821X(88)90031-3

Goldstein, S. L., and Hemming, S. R. (2003). "Long-lived isotopic tracers in oceanography, paleoceanography, and ice-sheet dynamics," in Treatise on Geochemistry, Vol. 6, eds H. Elderfield, H. D. Holland, and K. T. Turekian, (Oxford: Elsevier-Pergamon), 453-489. doi: 10.1016/b0-08-043751-6/06179-x

Gottselig, N., Amelung, W., Kirchner, J. W., Bol, R., Eugster, W., Granger, S. J., et al. (2017). Elemental composition of natural nanoparticles and fine colloids in European forest stream waters and their role as phosphorus carriers. Global Biogeochem. Cycles 31, 1592-1607. doi: 10.1002/2017GB005657

Hartmann, J., and Moosdorf, N. (2012). The new global lithological map database GLiM: a representation of rock properties at the Earth surface. Geochem. Geophys. Geosyst. 13:Q12004. doi: 10.1029/2012GC004370 
Hill, D. M., and Aplin, A. C. (2001). Role of colloids and fine particles in the transport of metals in rivers draining carbonate and silicate terrains. Limnol. Oceanogr. 46, 331-344. doi: 10.4319/lo.2001.46.2.0331

Hill, P. J., De Deckker, P., von der Borch, C., and Murray-Wallace, C. V. (2009). Ancestral Murray River on the Lacepede shelf, southern Australia: late quaternary migrations of a major river outlet and strandline development. Aust. J. Earth Sci. 56, 135-157. doi: 10.1080/08120090802546993

Hoffmann, L. J., Breitbarth, E., Ardelan, M. V., Duggen, S., Olgun, N., Hassellöv, M., et al. (2012). Influence of trace metal release from volcanic ash on growth of Thalassiosira pseudonana and Emiliania huxleyi. Mar. Chem. 132, 28-33. doi: 10.1016/j.marchem.2012.02.003

Jonell, T. N., Li, Y., Blusztajn, J., Giosan, L., and Clift, P. D. (2018). Signal or noise? Isolating grain size effects on $\mathrm{Nd}$ and $\mathrm{Sr}$ isotope variability in Indus delta sediment provenance. Chem. Geol. 485, 56-73. doi: 10.1016/j.chemgeo.2018. 03.036

Jones, M. T., and Gislason, S. R. (2008). Rapid releases of metal salts and nutrients following the deposition of volcanic ash into aqueous environments. Geochim. Cosmochim. Acta 72, 3661-3680. doi: 10.1016/j.gca.2008.05.030

Kingham, R. (1998). Geology of the Murray-Darling Basin: simplified lithostratigraphic groupings. Australian geological survey organisation, department of primary industries \& energy.

Korsch, M. J., and Gulson, A. Y. (1986). Nd and Pb isotopic studies of an Archean layered mafic-ultramafic complex, Western Australia, and implications for mantle heterogeneity. Geochim. Cosmochim. Acta 50, 1-10. doi: 10.1016/00167037(86)90042-6

Kulaksiz, S., and Bau, M. (2013). Anthropogenic dissolved and colloid/nanoparticle-bound samarium, lanthanum and gadolinium in the Rhine River and the impending destruction of the natural rare earth element distribution in rivers. Earth Planet. Sci. Lett. 362, 43-50. doi: 10.1016/j.epsl.2012.11.033

Lawrence, M. G., Greig, A., Collerson, K. D., and Kamber, B. S. (2006). Rare earth element and yttrium variability in South East Queensland waterways. Aquat. Geochem. 12, 39-72. doi: 10.1007/s10498-005-4471-8

Leybourne, M. I., and Johannesson, K. H. (2008). Rare earth elements (REE) and yttrium in stream waters, stream sediments, and $\mathrm{Fe}-\mathrm{Mn}$ oxyhydroxides: fractionation, speciation, and controls over REE+ Y patterns in the surface environment. Geochim. Cosmochim. Acta 72, 5962-5983. doi: 10.1016/j.gca. 2008.09.022

Lopes dos Santos, R. A., De Deckker, P., Hopmans, E. C., Magee, J. W., Mets, A., Damsté, J. S. S., et al. (2013). Abrupt vegetation change after the Late Quaternary megafaunal extinction. Nat. Geosci. 6, 627-631. doi: 10.1038/ngeo1856

Lugmair, G. W., Shimamura, T., Lewis, R. S., and Anders, E. (1983). Samarium-146 in the early solar system: evidence from Neodymium in the Allende Meteorite. Science 222, 1015-1018. doi: 10.1126/science.222.4627.1015

Martin, C. E., and McCulloch, M. T. (1999). Nd-Sr isotopic and trace element geochemistry of river sediments and soils in a fertilized Catchment, New South Wales, Australia. Geochim. Cosmochim. Acta 63, 287-305. doi: 10.1016/S00167037(98)00308-1

McDonough, W. F., McCulloch, M. T., and Sun, S. S. (1985). Isotopic and geochemical systematics in Tertiary-Recent basalts from southeastern Australia and implications for the evolution of the sub-continental lithosphere. Geochim. Cosmochim. Acta 49, 2051-2067. doi: 10.1016/0016-7037(85)90063-8

McLennan, S. M. (1989). "Rare earth elements in sedimentary rocks: influence of provenance and sedimentary processes," in Reviews in Mineralogy. Geochemistry and Mineralogy of Rare Earth Elements, Vol. 21, eds B. R. Lippin, and G. A. McKay, (Chantilly, VA: Mineralogical Society of America), 169-200. doi: 10. 1515/9781501509032-010

McLennan, S. M., McCulloch, M. T., Taylor, S. R., and Maynard, J. B. (1989). Effect of sedimentary sorting on neodymium isotopes in deep-sea turbidites. Nature 337, 547-549. doi: $10.1038 / 337547 \mathrm{a} 0$

Merschel, G., Bau, M., Schmidt, K., Münker, C., and Dantas, E. L. (2017). Hafnium and neodymium isotopes and REY distribution in the truly dissolved, nanoparticulate/colloidal and suspended loads of rivers in the Amazon Basin, Brazil. Geochim. Cosmochim. Acta 213, 383-399. doi: 10.1016/j.gca.2017.07.006

Milliman, J. D., and Farnsworth, K. L. (2011). River Discharge to the Coastal Ocean, A Global Synthesis. Cambridge: Cambridge University Press, 392.

Nozaki, Y., Zhang, J., and Amakawa, H. (1997). The fractionation between Y and $\mathrm{Ho}$ in the marine environment. Earth Planet. Sci. Lett. 148, 329-340. doi: 10.1016/S0012-821X(97)00034-4
Olgun, N., Duggen, S., Croot, P. L., Delmelle, P., Dietze, H., Schacht, U., et al. (2011). Surface ocean iron fertilization: the role of airborne volcanic ash from subduction zone and hot spot volcanoes and related iron fluxes into the Pacific Ocean. Global Biogeochem. Cycles25:GB4001. doi: 10.1029/2009GB00 3761

Palfreyman, W. D., D’Addario, G. W., Swoboda, R. A., Bultitude, J. M., and Lamberts, I. T. (1976). Geology of Australia, 1: 2500 000. Bureau of Mineral Resources. Canberra: Geology and Geophysics.

Pokrovsky, O. S., and Schott, J. (2002). Iron colloids/organic matter associated transport of major and trace elements in small boreal rivers and their estuaries (NW Russia). Chem. Geol. 190, 141-179. doi: 10.1016/S0009-2541(02)00115-8

Price, R. C., Gray, C. M., Wilson, R. E., Frey, F. A., and Taylor, S. R. (1991). The effects of weathering on rare-earth element, $\mathrm{Y}$ and Ba abundances in Tertiary basalts from southeastern Australia. Chem. Geol. 93, 245-265. doi: 10.1016/ 0009-2541(91)90117-A

Prudêncio, M. I., Gouveia, M. A., and Braga, M. S. (1995). REE distribution in present-day and ancient surface environments of basaltic rocks (central Portugal). Clay Miner. 30, 239-248. doi: 10.1180/claymin.1995.030.3.07

Rousseau, T. C., Sonke, J. E., Chmeleff, J., Van Beek, P., Souhaut, M., Boaventura, G., et al. (2015). Rapid neodymium release to marine waters from lithogenic sediments in the Amazon estuary. Nat. Commun. 6:7592. doi: 10.1038/ ncomms 8592

Sholkovitz, E., and Szymczak, R. (2000). The estuarine chemistry of rare earth elements: comparison of the Amazon, Fly, Sepik and the Gulf of Papua systems. Earth Planet. Sci. Lett. 179, 299-309. doi: 10.1016/S0012-821X(00)00112-6

Sholkovitz, E. R. (1992). Chemical evolution of rare earth elements: fractionation between colloidal and solution phases of filtered river water. Earth Planet. Sci. Lett. 114, 77-84. doi: 10.1016/0012-821X(92)90152-L

Tepe, N., and Bau, M. (2014). Importance of nanoparticles and colloids from volcanic ash for riverine transport of trace elements to the ocean: evidence from glacial-fed rivers after the 2010 eruption of Eyjafjallajökull Volcano, Iceland. Sci. Total Environ. 488, 243-251. doi: 10.1016/j.scitotenv.2014.04.083

Tepe, N., and Bau, M. (2016). Behavior of rare earth elements and yttrium during simulation of arctic estuarine mixing between glacial-fed river waters and seawater and the impact of inorganic (nano-) particles. Chem. Geol. 438, 134-145. doi: 10.1016/j.chemgeo.2016.06.001

Tranvik, L. J., Sherr, E., and Sherr, B. F. (1993). Uptake and utilization of 'colloidal DOM' by heterotrophic flagellates in seawater. Mar. Ecol. Prog. Ser. 92, 301-309. doi: 10.3354/meps092301

Trifuoggi, M., Donadio, C., Ferrara, L., Stanislao, C., Toscanesi, M., and Arienzo, M. (2018). Levels of pollution of rare earth elements in the surface sediments from the Gulf of Pozzuoli (Campania, Italy). Mar. Pollut. Bull. 136, 374-384. doi: 10.1016/j.marpolbul.2018.09.034

Trostle, K. D., Runyon, J. R., Pohlmann, M. A., Redfield, S. E., Pelletier, J., McIntosh, J., et al. (2016). Colloids and organic matter complexation control trace metal concentration-discharge relationships in Marshall Gulch stream waters. Water Resour. Res. 52, 7931-7944. doi: 10.1002/2016WR01 9072

Viers, J., Dupré, B., and Gaillardet, J. (2009). Chemical composition of suspended sediments in World Rivers: new insights from a new database. Sci. Total Environ. 407, 853-868. doi: 10.1016/j.scitotenv.2008.09.053

Viers, J., and Wasseburg, G. J. (2004). Behavior of Sm and Nd in a lateritic soil profile. Geochim. Cosmochim. Acta 68, 2043-2054. doi: 10.1016/j.gca.2003. 10.034

Xu, N., Morgan, B., and Rate, A. W. (2018). From source to sink: rare-earth elements trace the legacy of sulfuric dredge spoils on estuarine sediments. Sci. Total Environ. 637, 1537-1549. doi: 10.1016/j.scitotenv.2018.04.398

Conflict of Interest: The authors declare that the research was conducted in the absence of any commercial or financial relationships that could be construed as a potential conflict of interest.

Copyright (C) 2020 Bayon, Douglas, Denton, Monin and De Deckker. This is an open-access article distributed under the terms of the Creative Commons Attribution License (CC BY). The use, distribution or reproduction in other forums is permitted, provided the original author(s) and the copyright owner(s) are credited and that the original publication in this journal is cited, in accordance with accepted academic practice. No use, distribution or reproduction is permitted which does not comply with these terms. 